\title{
Erythropoietin on a Tightrope: Balancing Neuronal and Vascular Protection between Intrinsic and Extrinsic Pathways
}

\author{
Faqi $\mathrm{Li}^{\mathrm{a}}$ Zhao Zhong Chong ${ }^{\mathrm{a}}$ Kenneth Maiese ${ }^{\mathrm{a}-\mathrm{d}}$ \\ aDivision of Cellular and Molecular Cerebral Ischemia, bepartments of Neurology and Anatomy and Cell Biology, \\ 'Center for Molecular Medicine and Genetics and Institute of Environmental Health Sciences, \\ Wayne State University School of Medicine, Detroit, Mich., USA
}

\section{Key Words}

Akt - Angiogenesis - Caspases · Forkhead transcription factors · Janus kinase $2 \cdot$ Microglia - Mitogen-activated protein kinases $\cdot$ Protein kinase $\mathrm{C} \cdot$ Stem cells

\begin{abstract}
Enthusiasm for erythropoietin (EPO) as a broad cytoprotective agent continues to increase at an almost exponential rate. The premise that EPO was required only for erythropoiesis was eventually shed by recent work demonstrating the existence of EPO and its receptor in other organs and tissues outside of the liver and the kidney, such as the brain and heart. As a result, EPO has been identified as a possible candidate in the formulation of therapeutic strategies for both cardiac and nervous system diseases. EPO has been shown to mediate an array of vital cellular functions that involve progenitor stem cell development, cellular protection, angiogenesis, DNA repair, and cellular longevity. An important requirement to achieve the goal of preventing or even reducing cellular injury by any cytoprotective agent is the ability to uncover the cellular pathways that ultimately drive a cell to its demise. We present for consideration several critical cellular pathways modulated by EPO that involve Janus kinase 2 (Jak2), the serine-threonine kinase Akt,
\end{abstract}

\section{KARGER}

Fax +41613061234

E-Mail karger@karger.ch

www.karger.com (c) 2004 S. Karger AG, Basel

$1424-862 X / 04 / 0136-0265 \$ 21.00 / 0$

Accessible online at:

www. karger.com/nsg forkhead transcription factors, glycogen synthase kinase-3 $\beta$ (GSK-3 $\beta$ ), cellular calcium, protein kinase $C$, caspases, as well as the control of inflammatory microglial pathways, EPO should emerge as a critical agent for the development, maturation, and survival of cells throughout the body.

Copyright $(2004$ S. Karger AG, Base

\section{Introduction}

Erythropoietin (EPO) is initially produced in the fetal liver during development, but shortly after birth, the generation of EPO is subsequently shifted to the kidney [1]. One of the primary functions of EPO, which is fostered by the activation of the EPO receptor (EPOR) and subsequent signal transduction pathways, is to promote proliferation, differentiation, and survival of erythroid progenitors resulting in the increased production of red blood cells. Erythropoiesis was originally considered to be the only physiological action of EPO. This concept was subsequently overturned by the knowledge that EPO and the EPOR are expressed in other organs and tissues outside of the liver and the kidney, such as the brain, heart, and uterus. In addition, several cell populaactivation. As we continue to gain new insight into these

Kenneth Maiese, MD

Department of Neurology, 8C-1 UHC, Wayne State University School of Medicine

4201 St. Antoine, Detroit, MI 48201 (USA)

Tel. +1 3139660833, Fax +1 3139660486

E-Mailkmaiese@med.wayne.edu, aa2088@wayne.edu 
Fig. 1. EPO acts upon a wide variety of cells that include neurons, vascular cells, and cardiac cells to prevent cellular inflammation, block apoptotic injury, and foster angiogenesis. EPO acts directly upon the survival of neurons, ECs, cardiomyocytes, vascular smooth muscle cells (VSMC), renal cells as well as promoting cell development in progenitor stem cells and the induction of angiogenesis. EPO also modulates microglial activity to block harmful cytokine release and prevent the phagocytosis of cells 'tagged' by cellular phosphatidylserine membrane exposure. GMCs = Gastric mucosal cells; PECs = prostate epithelial cells.

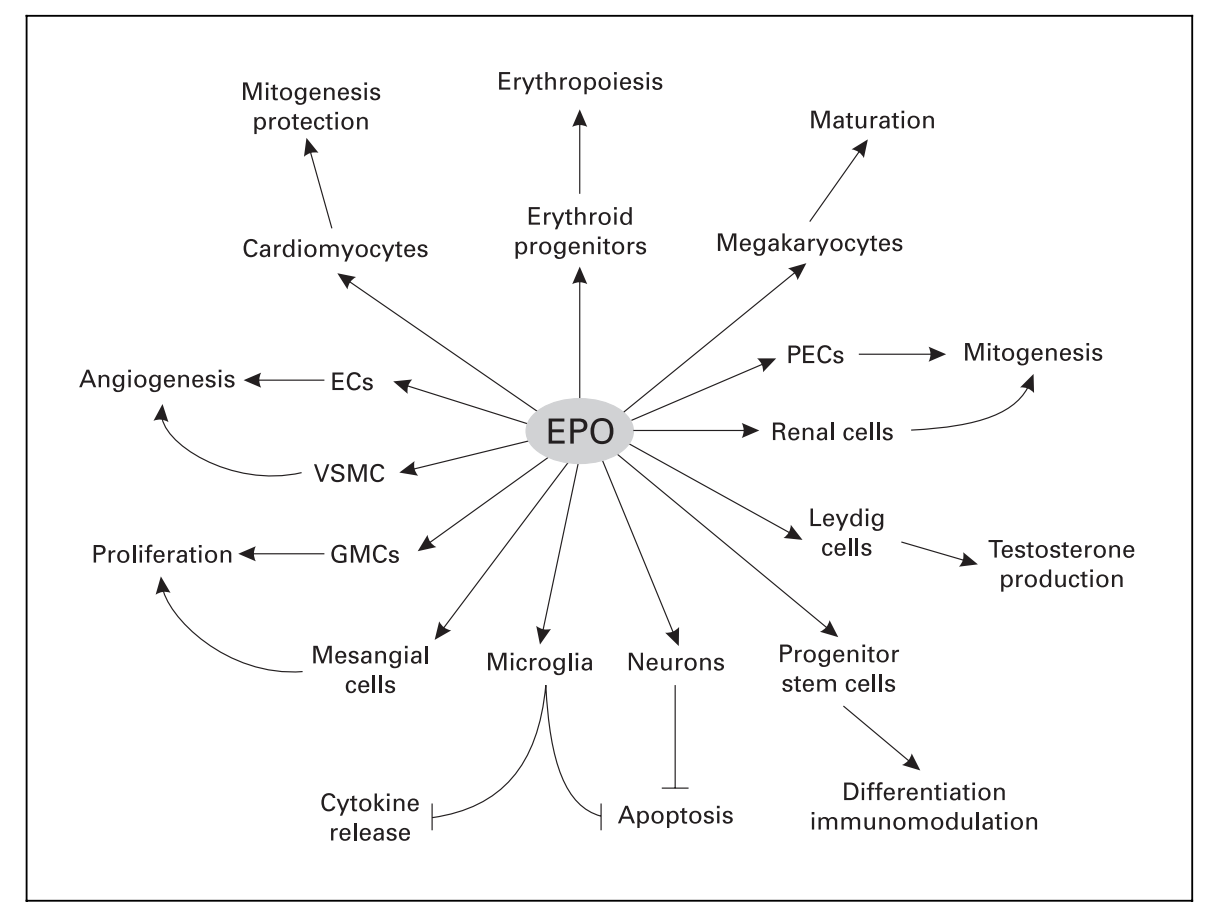

tions also harbor expression of both EPO and the EPOR including neuronal, cardiac, and endothelial cells (ECs) (fig. 1). As a result, the function of EPO is now known to extend broadly beyond erythropoiesis. For example, EPO may play a role in the cardiovascular system by preventing ischemic heart disease injury. The expression of EPO in the central nervous system (CNS) also may suggest a potential cytoprotective function for this protein during nervous system disorders. In this review, we will focus on the role of EPO in systems of both neuronal and cardiovascular origins as a possible protective agent that may be applicable for immediate and longterm therapeutic regimens.

\section{The Molecular Determinants for the Biological Activity of EPO}

The EPO gene is located on chromosome 7, exists as a single copy in a 5.4-kb region of the genomic DNA, and encodes a polypeptide chain containing 193 amino acids [2]. During the production and secretion of EPO, a 166amino acid peptide is initially generated following the cleavage of a 27 -amino acid hydrophobic secretory leader at the amino-terminal. In addition, a carboxy-terminal arginine in position 166 is removed both in the mature human and recombinant human EPO (rhEPO) [3]. As a result, the circulatory mature protein of EPO has a span of 165 amino acids.

$\mathrm{EPO}$ is a $30.4-\mathrm{kDa}$ glycoprotein and the carbohydrate content contributes to approximately $40 \%$ of its molecular weight. There are four glycosylated chains including three $\mathrm{N}$-linked and one O-linked acidic oligosaccharide side chains. N-linked glycosylation sites occur at the positions 24,38 and 83 of aspartyl residues, while the Olinked glycosylation site is at $\mathrm{Ser}^{126}$. Three N-glycan chains of human EPO consist of the tetra-antennary structure with or without $\mathrm{N}$-acetyllactosamine repeating units [4]. The O-linked sugar chain is composed of Gal-GalNAc and sialic acids [5].

The glycosylated chains are required for the biological activity of EPO. Human EPO is stabilized by the carbohydrate chains [6] and the oligosaccharides in EPO may protect the EPO protein structure from oxygen radical activity [7]. The N-glycosylated chains contribute to the thermal stability of EPO [4]. In addition, the $\mathrm{N}$ - and O-linked chains may be necessary for the production and secretion of the mature EPO [8]. Replacement of asparagines 38 and 83 by glutamate or serine 126 by glycine can decrease the production and secretion of EPO [9]. The presence of the carbohydrates also are important in the control of the metabolism of EPO, since EPO molecules with high sialic 
acid content can be easily cleared by the body through specific binding in the liver [10].

The biological activity of EPO also relies upon two disulfide bonds formed between cysteines at positions 7 and 160 and at positions 29 and 33. The requirement of these disulfide bridges has been demonstrated by the evidence that reduction of these bonds results in the loss of the biological activity of EPO. Alkylation of the sulfhydryl groups results in irreversible loss of the biological activity of EPO. Reoxidization of EPO after reduction by guanidine $\mathrm{HCl}$ leads to regeneration of $85 \%$ of the biological activity of EPO [11]. In addition, Cys ${ }^{33}$ replacement with proline also reduces the biological function of EPO. These results suggest that the two disulfide bridges are critical for EPO to serve its biological function.

\section{Organs of Production and Expression for EPO and Its Receptor}

Over time, a combination of studies have shown that the main organs of EPO production and secretion are the kidney, liver, brain, and uterus (fig. 1). The primary site of EPO production and secretion is in the kidney. The peritubular interstitial cells in the kidney are responsible for production and secretion of EPO [12]. With the use of cDNA probes derived from the EPO gene, peritubular ECs, tubular epithelial cells, and nephron segments in the kidney also have been demonstrated to be vital cells for the production and secretion of EPO [13, 14].

Secondary sites of EPO production and secretion involve the liver and the uterus. Studies have indicated that hepatocytes, hepatoma cells, and Kupffer cells of the liver can produce and secrete EPO [12]. In regard to the uterine production of EPO, it is believed that the hypoproliferative neonatal anemia that invariably occurs in the early weeks after birth may partly result from the loss of EPO production and secretion by placenta [15]. As knowledge of the sites for the generation of EPO increases, other novel organs, tissues, and cells continue to surface as secretory tissues for EPO that include ECs, enterocytes, muscle (skeletal, smooth, and cardiac), and insulin-producing cells [16-19].

Yet of all the newly identified sites for the existence of EPO and its receptor, it is the production of EPO in the brain that has generated a significant level of interest and enthusiasm for further investigation. Production and secretion of EPO have been illustrated in the nervous system of rodents, primates, and humans [20-22]. In the brain, the major sites of EPO production and secretion are in the hippocampus, internal capsule, cortex, midbrain, cerebral ECs, and astrocytes. Interestingly, studies that involve electrical stimulation of the brain have indicated that EPO may be produced by a diverse system of secretory cells [23].

EPO must bind to a target cell surface receptor to bring into play its biological function. Once the EPO gene was cloned [2], work was initiated to identify a receptor for EPO. The EPOR was found to be expressed in both normal and transformed erythroid cells [24]. EPO regulates bone marrow erythroid cell proliferation, differentiation, and survival through its binding to an erythroid progenitor cell surface EPOR. Additional work has documented the presence of the EPOR in numerous nonerythroid blood lines including myeloid cells, lymphocytes, and megakaryocytes as well as multiple nonhematopoietic cells, such as neurons, microglia, astrocytes, vascular smooth muscle cells, cardiomyocytes, mesangial cells, prostate cells and renal cells [16, 20-22, 25] (fig. 1). Recent work has even documented the presence of the EPOR on myelin sheaths of radicular nerves in human peripheral nerves [26], suggesting both a developmental and cytoprotective role for EPO not only during CNS disorders, but also in disease entities that involve the peripheral nervous system. The EPOR also is expressed in primary cerebral ECs [20,27]. In addition, expression of the EPOR mRNA in ECs occurs in human umbilical veins, bovine adrenal capillaries, and rat brain capillaries [16, 28]. Binding studies with radioiodinated rhEPO has revealed that approximately 27,000 EPORs with an affinity in the $10^{-9} \mathrm{M}$ range are present on each EC.

\section{Temporal and Environmental Modulation of EPO}

The production of EPO and the expression of EPOR can vary significantly during the development of an organism. Elevated expression of the EPOR occurs in early embryonic murine neuronal tissues at levels similar to that observed in the adult spleen and bone marrow [29]. The level of endogenous EPOR expression is significantly reduced following the maturation of the brain [30]. In the human nervous system, the level of EPO production is also known to change with development from increased production during gestation to decreased production after birth.

Following development, the production and secretion of EPO and the expression of EPOR are regulated by the tissue oxygen supply. Plasma levels of EPO are increased 
up to 1,000-fold above normal levels in response to hypoxia [1]. A deficiency in tissue oxygen results in the production of EPO and an increase in the expression of the EPOR not only in the kidney and liver [22], but also in the brain [20, 22]. During hypoxia, EPO production may originate in the brain, possibly crossing the blood-brain barrier to reach the blood and peripheral organs [31]. The hypoxia-dependent production and secretion of EPO in the brain appear to be more sustained than in peripheral organs such as the kidney [32]. Additional studies in the brains of rodents and primates subjected to systemic hypoxia also demonstrate an increase in expression of EPO and EPOR mRNA following reduced oxygenation [33]. Furthermore, neuronal cell lines have been found to retain the capacity to express the EPO gene in an oxygendependent manner [34]. Cerebral ischemia that leads to a deficiency of brain oxygen can result in a significant increase in the expression of EPO and the EPOR in neurons, astrocytes, and cerebral microvascular ECs in mice [35].

As expected, EPO is recognized as a critical modulator of erythroid production known as erythropoiesis. However, a diminished concentration of red blood cells does not directly stimulate EPO production and secretion as one would predict. Production and secretion of EPO for the stimulation of erythropoiesis are also oxygen dependent. Once a hypoxic stimulus is received, EPO is subsequently released into the peripheral blood circulation and upon arrival in the bone marrow, EPO binds to its receptor expressed on the surface of erythroid progenitor cells and leads to erythropoiesis [36]. This results in an elevation in the number of mature erythrocytes and the improvement of oxygen supply [37]. Interestingly, EPO also acts on the later stages of erythroid progenitor cells. EPO functions to stimulate colony-forming erythroid cells to induce these cells to proliferate and mature into erythrocytes [12].

In most tissues including the brain, hypoxia-dependent expression of EPO and EPOR are primarily regulated by hypoxia-inducible factor 1 (HIF-1), an alpha/beta heterodimeric protein that is activated by a variety of stressors, such as hypoxia. HIF-1 is essential for the production and secretion of EPO in response to hypoxia. At the transcriptional level, the hypoxia-dependent gene transcription of EPO and EPOR directly results from the activation of the HIF-1 pathway under hypoxic conditions [38]. Gene transcription of EPO is mediated by the transcription enhancer located in the 3 '-flanking region of the EPO gene that specifically binds to HIF-1 [39].
HIF-1 is a basic helix-loop-helix heterodimeric transcription factor containing two subunits, HIF-1 $\alpha$ and HIF-1 $\beta$ [39]. HIF-1 $\beta$ is a constitutively expressed 91- to 94-kDa subunit that was characterized previously as aryl hydrocarbon receptor nuclear translocator (ARNT) [40]. HIF- $1 \alpha$ is a $120-k D a$ oxygen-labile subunit that undergoes rapid degradation via the ubiquitin-proteasome pathway under normoxic conditions [41]. Upon hypoxic exposure, degradation of HIF- $1 \alpha$ is impaired by blocking its association with von Hippel-Lindau protein that targets HIF-1 $\alpha$ for proteasome destruction [42]. HIF-1 $\alpha$ translocates to the nucleus and heterodimerizes with HIF-1 $\beta$ to form a stable HIF-1 complex. The HIF complex binds to the conserved sequence (5'-RCGTG-3') near the $5^{\prime}$ end of the hypoxia-responsive enhancer of the EPO gene to upregulate EPO gene transcription [43]. Increased DNA binding activity of HIF-1 has been observed in rat cortical neurons during oxidative stress $[44,45]$. These results suggest that HIF-1 may function as oxygen sensor regulating adaptive gene transcription and resulting in the production and secretion of the EPO protein during hypoxia in the CNS. Recent studies have shown that each of the family members of HIF that include HIF- $1 \alpha$, HIF- $1 \beta$, and HIF-3 $\alpha$ appear to play an important role in regulating the expression of EPO and the EPOR to foster protection against hypoxic cell injury [46].

Hypoxia is not the only factor involved in the expression of EPO and the EPOR. For example, the production and secretion of EPO in female reproductive organs is estrogen dependent. Administration of $17 \beta$-estradiol $\left(\mathrm{E}_{2}\right)$, which controls the cyclic development of the uterine endometrium, can lead to a rapid and transient increase in EPO mRNA in the uterus [47]. Hypoxic-induced EPO mRNA expression in uterine tissue occurs only in the presence of $E_{2}$. This induction of EPO mRNA expression by hypoxia in the uterus is less pronounced than the EPO expression that occurs in the kidney and the brain [32]. Oviduct and ovary production of EPO is also $E_{2}$ dependent [48]. Other metabolic disturbances, such as hypoglycemia, raised intracellular calcium, or intense neuronal depolarizations generated by mitochondrial reactive oxygen species, may increase cerebral EPO expression through activation of HIF [20, 21, 49]. Anemic stress and insulin release also can lead to increased expression of EPO and the EPOR in both neuronal and nonneuronal cell populations. Finally, a variety of cytokines, including insulin-like growth factor, tumor necrosis factor- $\alpha$ (TNF$\alpha$ ), interleukin-1 $\beta$ (IL-1 $\beta$ ), and interleukin-6 (IL-6), can regulate the production and secretion of EPO [50]. 


\section{EPO Leads to Progenitor Stem Cell Development in Nonerythroid Cells}

EPO can assist with the proliferation and development of progenitor stem cells (fig. 1). EPO can increase the viability of embryonic cortical neurons, promote cell surviv$\mathrm{al}$, and upregulate the proliferative response of neuronal progenitor cells [51]. At times, EPO will selectively promote the production of neuronal progenitors at the expense of other multipotent progenitors [52]. Similar to other hematopoietic factors, EPO also can function as a neurotrophic factor for differentiated cells. For example, EPO can influence the regeneration, differentiation, and survival of central cholinergic neurons as well as mediate the differentiation of mesencephalic precursors into dopaminergic neurons [53, 54].

\section{EPO Possesses a Robust Potential for Cytoprotection}

\section{EPO in the CNS}

The adaptive response to oxygen deficiency that results in increasing production and secretion of EPO as well as the enhanced expression of the EPOR in the CNS suggests a strong potential role for EPO to prevent brain injury. Efforts to illustrate neuronal and vascular protection in the CNS by EPO have been performed using multiple in vivo and in vitro experimental models (table 1). Initial animal studies focused on the ability of EPO to reduce cerebral injury following an ischemic insult and to maintain cognitive function. One of the first experimental studies performed infused EPO into the lateral ventricles of gerbils subjected to occlusion of the common carotid artery and demonstrated that cerebroventricular administration of EPO in a concentration range of 2.5-24 units/ day for 7 days prevented ischemic-induced learning disability, reduced hippocampal neuronal injury, and ameliorated neuron survival in the gerbil [55]. Infusion of EPO into the lateral ventricles of mice $24 \mathrm{~h}$ prior to the onset of a middle cerebral artery occlusion also resulted in a significant reduction in cerebral infarct volume [35]. Other work demonstrated that injection of EPO into the ventricles of stroke-prone spontaneously hypertensive rats with permanent occlusion of the left middle cerebral artery alleviated ischemia-induced navigation disability, supported neuron survival, and limited the degree of infarction [56, 57].

Over time, ventricular delivery systems have been considered impractical for clinical applications. As a result, future investigations are now pursuing systemic administration of EPO in several injury models. Systemic application of EPO has been demonstrated to prevent delayed hippocampal neuronal injury following global cerebral ischemia in gerbils [58] and direct intravenous infusion of naked plasmid containing EPO cDNA is capable of rescuing neurons from lethal hypoxia-ischemia injury [59]. Application of systemic EPO following experimental subarachnoid hemorrhage also has been shown to effectively modulate the autoregulation of cerebral blood flow, reverse vasoconstriction of the basilar arteries, reduce ischemic neuronal damage, and enhance functional recovery [60].

Investigations examining the potential of EPO to prevent cortical injury have been extended to spinal cord models, the visual system, and the peripheral nervous system. During spinal cord ischemia as well as spinal cord blunt injury, EPO can prevent motor neuronal apoptosis and neurological disability, attenuate secondary inflammatory injury, and reduce lipid peroxidation [61]. In transient global retinal ischemia and ischemia-reperfusion injury models, systemic administration of EPO before or immediately after retinal ischemia can protect retinal ganglion cells from apoptosis and promote the recovery of retinal function [21, 62]. It is believed that EPO promotes neural outgrowth from retinal ganglion cells that possess EPORs [63]. Additional studies in the adult mouse hypoxic retina has shown that systemically applied EPO can cross the blood-retina barrier and prevent apoptosis during a light-induced insult [64]. These findings strongly suggest that application of EPO may be beneficial for the treatment of a variety of retinal diseases by blocking apoptotic degeneration of photoreceptors or retinal ganglion cells. In peripheral nerve injury models, therapy with EPO can significantly decrease dorsal root ganglion apoptosis, improve recovery rates from mechanical allodynia [65], and promote myelin repair [66], suggesting that EPO may play an important role in the treatment of neuropathic pain as well as diseases that involve degeneration of motor neurons.

\section{EPO Protects Vascular Integrity and Promotes Angiogenesis}

Since cerebral ischemia can impair the integrity of the blood-brain barrier, it is hypothesized that EPO can acquire access to cerebral tissue through regions of bloodbrain barrier breakdown and may ultimately assist with the repair of the blood-brain barrier [60,67]. Without injury to the blood-brain barrier, EPO may not gain access to the brain [68]. On closer inspection, recent work 
Table 1. EPO in the nervous system

\section{Experimental models}

Animal model studies

$5-5,000 \mathrm{U} / \mathrm{kg}$ i.p. or $10-50 \mathrm{U} / \mathrm{kg}$ ( or $0.4 \mu \mathrm{g} / \mathrm{kg}$ ) i.v. or

$0.2-25 \mathrm{U} /$ day i.c.v. applied either pretreatment or posttreatment with injury in rats, mice, or gerbils

\section{Retinal ischemia}

$5,000 \mathrm{U} / \mathrm{kg}$ i.p. or $2 \mu \mathrm{l}$ intravitreal applied either pre-

\section{Neonatal hypoxic-ischemic brain injury}

300-5,000 U/kg i.p. applied either pretreatment or posttreatment with injury in mice and rats

Spinal cord ischemic injury

$100-5,000 \mathrm{U} / \mathrm{kg}$ i.p. or 10-1,000 U/kg i.v. application posttreatment with injury in rats or rabbits

Subarachnoid hemorrhage

$1,000 \mathrm{U} / \mathrm{kg}$ i.p. or $400 \mathrm{U} / \mathrm{kg}$ s.c. applied immediately or

5 min after injury in rats or rabbits
Focal and global cerebral ischemia treatment or posttreatment with injury in mice and rats

\section{Role of EPO}

References

Infarct volume, brain edema, and neuronal apoptosis decreased; neuronal survival and cerebral functional recovery increased

Ganglion and photoreceptor cell apoptosis decreased

63,164

Infarct volume, neuronal apoptosis, NO production, and caspase 3 activity decreased

Motor neuronal apotosis, inflammation, and lipid peroxidation decreased; neuronal survival increased; functional recovery improved

Rat mortality, neuronal death, and vasoconstriction decreased; functional recovery and blood flow autoregulation improved

Cerebral inflammation

$500-5,000 \mathrm{U} / \mathrm{kg}$ i.p. applied immediately after injury in rats

Brain injury and inflammatory cytokine release decreased

61,118

Peripheral nerve injury

$1,000-5,000 \mathrm{U} / \mathrm{kg}$ s.c. or $1-10 \mathrm{U} / \mathrm{kg}$ i.v. applied

pretreatment with injury in rats

Dorsal root ganglion and spinal neuronal apoptosis decreased;

64,65 myelin repair; recovery from mechanical allodynia improved

Tissue culture studies

Anoxic injury

$0.01-100 \mathrm{ng} / \mathrm{ml}$ applied either pretreatment or posttreatment with injury in ECs, hippocampal, or cortical neurons

DNA fragmentation and PS exposure decreased;

NO injury

cell survival increased

$10 \mathrm{ng} / \mathrm{ml}, 20 \mathrm{U} / \mathrm{ml}, 25 \mathrm{U} /$ day applied either pretreatment or posttreatment with injury in ECs, hippocampal and cortical neurons
DNA fragmentation, PS exposure and NO production

decreased; cell survival increased
$27,55,58$ 105,117 , 123

Glutamate toxicity

$50 \mathrm{ng} / \mathrm{ml}$ or $3-300 \mathrm{pmol} / \mathrm{ml}$ applied pretreatment with injury in hippocampal, cortical and cerebellar neurons

Glutamate release decreased; neuronal survival increased

$35,122,149$

\section{BBB disruption}

$10 \mathrm{U} / \mathrm{ml}$ applied with VEGF $(10 \mathrm{ng} / \mathrm{ml})$ in monolayer of bovine brain ECs

\section{Stem cell development}

$0.5-15 \mathrm{U} / \mathrm{ml}$ applied immediately pretreatment to neuronal

BBB permeability decreased cholinergic or dopaminergic stem cells, human fetal increased neuronal cells and rat embryonic neuronal cells

Angiogenesis

0.5-100 U/ml applied immediately pretreatment in EC cultures

Intussusceptive microvascular growth, neovascularization, proliferation, and migration increased

$51-54$

Apoptosis decreased; neuronal progenitor cell number

$\mathrm{BBB}=$ Blood-brain barrier; i.c.v. $=$ intracerebroventricular injection; i.p. $=$ intraperitoneal injection; i.v. $=$ intravenous injection; s.c. $=$ subcutaneous injection; VEGF = vascular endothelial growth factor. 
has demonstrated that EPO can prevent blood-brain barrier permeability during injury and maintain the establishment of cell-to-cell junctions [67]. More importantly, EPO can provide direct cerebral EC protection and protect against nuclear degeneration during oxidative stress [25, 27, 69].

Yet, the role of EPO during vascular protection extends beyond the direct preservation of EC integrity and significantly involves angiogenesis, a complex process that consists of new capillary formation from preexisting vessels into an avascular area [25]. This process involves vascular basal lamina formation, migration of ECs, and alignment of migrating cells for tubular formation. There are at least two types of angiogenesis. Sprouting angiogenesis is characterized by the proliferation and migration of ECs into vascular sites [70]. In contrast, nonsprouting angiogenesis or intussusceptive microvascular growth occurs by splitting the existing vasculature into transluminal pillars or transendothelial bridges [71]. Angiogenesis takes place in various physiological and pathophysiological conditions. It is physiologically active during embryogenesis [70]. In the adult, it occurs during more limited periods such as during menstruation and during some pathological conditions such as wound healing, chronic inflammation, and tumor growth [72, 73].

EPO appears to elicit both a mitogenic and chemotactic effect. In cultured human and bovine ECs, EPO not only stimulates proliferation, but also enhances the migration of ECs [74]. In neonatal mesenteric microvascular ECs, EPO can promote vasculogenesis [75]. Other investigations have illustrated the migration of ECs on the Matrigel surface to form branching and anastomosing tubes in response to EPO exposure. Furthermore, EPO can lead to matrix metalloproteinase-2 production, cell proliferation, and vessel formation in EC lines [17].

In clinical studies, EPO serum levels are significantly associated with the number and function of circulating endothelial progenitor cells. In addition, EPO can stimulate postnatal neovascularization by increasing endothelial progenitor cell mobilization from the bone marrow [76]. Angiogenesis also has been observed in rat aortic rings 4 days following incubation with EPO in reconstituted basement membrane matrix [77] and in the ECs derived from human adult myocardial tissue treated by rhEPO [78]. Intussusceptive microvascular growth also is fostered by EPO and can be abolished by the application of an EPO-blocking antibody [79].

Both the uterine endometrium and the ovaries are dependent upon EPO for the induction of angiogenesis. Angiogenesis in the uterine endometrium functions to compensate for lost vessels during the estrus cycle. Injection of EPO into the uterine cavity of ovariectomized mice has been shown to be necessary to foster blood vessel formation in the endometrium [47]. EPO also regulates angiogenesis in the ovary and the subsequent formation of a capillary network for the development of follicles and the corpora lutea [47].

Angiogenesis generated in the vascular system by EPO also may provide indirect cellular protection in the CNS. The proliferation and migration of brain capillary ECs by EPO can occur during an ischemic brain, possibly offering enhanced blood flow and nutrients to ischemic cells starved for oxygen and nutrients [28, 35]. Furthermore, angiogenesis in the brain may be closely related to neuronal survival in patients with ischemic stroke [80]. A benefit of angiogenesis may result from the restoration of blood flow in the ischemic border through arteriolar growth and capillary formation during cerebral ischemia [81]. As new vessel formation occurs in the ischemic border of the brain several days following a stroke [80], the induction of angiogenesis by EPO may provide direct protection of brain neurons and ECs as well as indirectly contribute to the functional recovery of the ischemic brain through improved vascular perfusion $[25,35]$.

\section{EPO and Cardiac Function}

EPO may be considered to be a 'broad spectrum' cytoprotectant since in addition to promoting neuronal and vascular cell survival, protection by EPO involves several other cell populations including renal cells, pancreatic islet cells, and cardiomyocytes $[19,82]$. EPO may impact upon cardiovascular diseases as a result of its regulation of smooth muscle cells and the protection conferred upon vascular ECs and cardiomyocytes. The ability of EPO to preserve vascular ECs and induce angiogenesis as well as protect cardiac cells likely contributes to the significant protective role of EPO during cardiovascular injury such as ischemia, myocardial infarction, ischemia-reperfusion injury, and heart failure.

Given the positive effects of EPO against brain ischemia and reperfusion injury, recent studies both in vitro and in vivo have been conducted to evaluate the role of EPO during cardiac ischemia and reperfusion injury (table 2). In isolated hearts subjected to ischemia-reperfusion, treatment with EPO $24 \mathrm{~h}$ following injury can reduce apoptosis in cardiomyocytes, limit myocardial infarct size, and promote functional recovery of the heart [83]. Parenteral administration of EPO also is sufficient to induce dramatic protection against ischemia-reperfusion injury in the heart [84]. A more recent study has dem- 
Table 2. EPO in the cardiovascular system

\begin{tabular}{|c|c|c|}
\hline Experimental models & Role of EPO & References \\
\hline $\begin{array}{l}\text { Animal model studies } \\
\text { Myocardial ischemia-reperfusion injury } \\
1,000 \text { or } 5,000 \mathrm{U} / \mathrm{kg} \text { i.p. applied pretreatment with injury or } \\
100 \mathrm{U} / \mathrm{kg}(0.16 \mathrm{U} / \mathrm{ml}) \text { or } 10 \mathrm{U} / \mathrm{ml}(14-15 \mathrm{ml} / \mathrm{min} \text {, total } \\
1,500 \mathrm{U}) \text { perfused into isolated heart either pretreatment or } \\
\text { posttreatment with injury in rats, mice, or rabbits }\end{array}$ & $\begin{array}{l}\text { Myocardial infarct volume, myocardial apoptosis, and } \\
\text { caspase } 3 \text { activity decreased; survival of myocardiocytes, } \\
\text { ATP levels, and functional recovery increased; Jak2, } \\
\text { STAT3, STAT5, ERK and Akt activity increased }\end{array}$ & $\begin{array}{l}83,85,86, \\
93\end{array}$ \\
\hline $\begin{array}{l}\text { Myocardial infarction } \\
3,000-5,000 \mathrm{U} / \mathrm{kg} \text { i.p. or } 1,000-5,000 \mathrm{U} / \mathrm{kg} \text { i.v. applied } \\
\text { immediately or posttreatment with injury in rats or rabbits }\end{array}$ & $\begin{array}{l}\text { Myocardial infarct size, cardiac cell apoptosis, and LV size } \\
\text { decreased; cadiomyocyte survival, LV performance, ERK } \\
\text { and Akt activity increased }\end{array}$ & $88-90$ \\
\hline $\begin{array}{l}\text { Tissue culture studies } \\
\text { Anoxic injury } \\
100 \mathrm{ng} / \mathrm{ml} \text { or } 4-10 \mathrm{U} / \mathrm{ml} \text { applied either pretreatment or } \\
\text { posttreatment with injury in myocardiocytes, cardiac } \\
\text { fibroblasts, or } \mathrm{H} 9 \mathrm{c} 2 \text { myoblast cell line }\end{array}$ & $\begin{array}{l}\text { Myocardial apoptosis, overall cardiac cell death, and } \\
\text { caspase activity decreased; Jak1, Jak2, STAT3, STAT5, } \\
\text { ERK and Akt activity increased }\end{array}$ & $\begin{array}{l}85,88,89 \\
93\end{array}$ \\
\hline $\begin{array}{l}\text { Clinical studies } \\
\text { Heart failure } \\
2,000-30,000 \text { U/week, s.c. or i.v. application in the patients } \\
\text { with chronic heart failure }\end{array}$ & $\begin{array}{l}\text { Number of hospitalization days decreased; functional } \\
\text { recovery increased; clinical symptoms and signs improved }\end{array}$ & 94,95 \\
\hline
\end{tabular}

$\mathrm{Akt}=$ Protein kinase B; ERK = extracellular signal-related kinase; i.p. = intraperitoneal injection; i.v. = intravenous injection; $\mathrm{LV}=$ left ventricle; s.c. $=$ subcutaneous injection; STAT $=$ signal transducer and activator of transcription.

onstrated that EPO treatment either prior to or during myocardial ischemia/reperfusion can protect against myocardial cell apoptosis and decrease infarct size, resulting in enhanced cardiac function and recovery, including left ventricular contractility [85]. In the isolated rat heart following ischemia/reperfusion experiments, beneficial effects of treatment with EPO also have been shown to reduce cellular necrosis and improve postischemic recovery of left ventricular pressure significantly [86, 87]. At the onset of coronary artery occlusion, EPO administered also can significantly inhibit apoptosis in the central region of myocardial ischemia [88]. Even in acute scenarios following coronary artery ligation, EPO leads to a decrease in apoptotic cells by 50\% in the myocardium and significantly improves cardiac function [89, 90]. Current work has illustrated that EPO can promote intussusceptive microvascular growth in the heart, suggesting that the protective effect of EPO on ischemic heart disease may be a partial result from an increase in myocardium blood supply as a result of the generation of new blood vessels [79].
In addition to the correction of anemia, the beneficial effects of EPO on heart failure result from a direct protection of the myocardial cells. As a result, EPO is considered to be appropriate for the treatment of patients with heart failure following anemia or anemia accompanying heart failure. Early studies have indicated that administration of EPO can lead to a decrease in left ventricular hypertrophy, inhibit left ventricular dilatation, and increase left ventricular ejection fraction, stroke volume, and cardiac output, suggesting cardiac function improvement in patients with congestive heart failure resulted from anemia correction [91, 92]. Other in vivo studies have illustrated that treatment with EPO can increase cardiac cell proliferation in neonatal rats, reduce myocardiocyte apoptosis during ischemia-reperfusion injury, and improve left ventricular function $[89,90,93]$.

Recently, randomized control studies in patients with mild anemia and severe or resistant congestive heart failure have demonstrated that EPO in combination with intravenous iron can lead to increased left ventricular ejection fraction and a reduction in hospitalization days 
by almost $80 \%$ [94] (table 2). In additional investigations involving subcutaneous EPO in diabetics and nondiabetics with severe, resistant congestive heart failure breathlessness and/or fatigue have been shown to decrease, left ventricular ejection fraction to increase, and the number of hospitalization days to significantly decrease [95]. In patients with moderate to severe chronic heart failure, the peak oxygen consumption and exercise duration of patients are significantly increased following treatment with EPO, suggesting that EPO can enhance exercise capacity in patients with heart failure. As a result, work has supported the premise that EPO can function as a novel cytoprotectant against acute or chronic ischemic heart disease by enhancing cardiac cell survival and proliferation, increasing cardiovascular blood flow, and improving heart remodeling and function.

\section{EPO Drives Extrinsic Cellular Protection during Inflammatory Injury}

EPO can offer cytoprotection that extends beyond the preservation of intrinsic cellular integrity, such as preservation of genomic DNA integrity. EPO can influence extrinsic cell homeostasis through the modulation of microglial activation and the control of cytokine release (fig. 1). Microglia are monocyte-derived immunocompetent cells that enter the CNS during embryonic development and function similar to peripheral macrophages for the phagocytic removal of apoptotic cells. There exist several potential mechanisms that may regulate the phagocytosis of cells that have entered the apoptotic pathway. Some studies identify the generation of annexin I and membrane phosphatidylserine (PS) exposure that appears to be necessary to connect an apoptotic cell with a phagocyte [96]. Secreted factors by either apoptotic or phagocytic cells, such as milk fat globule-EGF factor 8 [97], fractalkine [98], and lipid lysophosphatidylcholine [99], also have been shown to assist with the phagocytic removal of injured cells.

The translocation of membrane PS residues from the inner cellular membrane to the outer surface appears to be critical for the removal of apoptotic cells [100-102]. The phospholipids of the plasma membrane are normally in an asymmetric pattern with the outer leaflet of the plasma membrane consisting primarily of choline-containing lipids, such as phosphatidylcholine and sphingomyelin, and the inner leaflets consisting of aminophospholipids that include phosphatidylethanolamine and PS. The loss of membrane phospholipid asymmetry leads to the external- ization of membrane PS residues and serves to identify cells for phagocytosis [102-105].

Both the induction of the phosphatidylserine receptor (PSR) on microglia and the exposure of membrane PS residues are necessary to activate microglia. Cells, such as neurons or ECs, exposed to injury can lead to the induction of both microglial activation and microglial PSR expression. Treatment with an anti-PSR neutralizing antibody in microglia prevents this microglial activation $[106,107]$ and application of PS directly results in microglial activation that can be blocked by a PSR-neutralizing antibody [102, 106], suggesting that both PS exposure in target cells and PSR expression in microglia are necessary for microglial recognition of apoptotic cells in the nervous system. Recognition of cellular membrane PS by the PSspecific receptors on microglia may require cofactors, such as Gas6 [108] or other agents, such as integrin and lectin [109].

Although vital for both cellular homeostasis as well as host defense mechanisms, microglia may aggravate a cellular insult. Studies with microglia stimulated by phorbol myristate acetate have demonstrated the release of superoxide radicals. Application of scavenger agents for reactive oxygen species, such as superoxide dismutase or deferoxamine mesylate, in the presence of activated microglia can prevent cellular injury. These studies suggest that oxidative stress generated by microglia can be responsible for cellular injury [110]. Activated microglia upregulate a variety of surface receptors and yield significant proinflammatory and neurotoxic factors, such as TNF- $\alpha$ and IL- $1 \beta$, free radicals such as nitric oxide (NO) and superoxide [111], and fatty acid metabolites such as eicosanoids that can precipitate cell death [112]. The secretion of cytokines by microglia also may represent another source of cytotoxicity for microglia. Microglia produce a variety of cytokines in response to toxic stimulation, such as interleukins and TNF. TNF- $\alpha$ production by microglia may be linked to neurodegeneration by increasing the sensitivity of neurons to free radical exposure [113].

Furthermore, several neurodegenerative disorders may progress during microglial activation. In Huntington's disease and amyotrophic lateral sclerosis, significant microglial activation occurs in areas of the nervous system that are specific for these disease entities $[114,115]$. During cerebral ischemia, activation of microglia parallels the induction of cellular apoptosis and correlates well with the severity of the ischemic insult [116]. In patients with Alzheimer's disease, microglial cells colocalize with the perivascular deposits of $\beta$-amyloid $(\mathrm{A} \beta)$. In addition, 
Fig. 2. EPO offers neuronal, vascular, and cardiac protection through a series of cellular pathways. The ability of EPO and the EPOR to enhance cell survival and block cell inflammation originates with upstream pathways that involve the Janus-tyrosine kinase 2 (Jak2) protein and protein kinase B (Akt). Downstream from the activation of Jak2 and Akt, EPO modulates STAT5, FOXO3a, GSK-3 $\beta, \quad B a d, \quad B c l-x_{L}, \quad I K K, \quad N F-\kappa B$, Gadd $45 \beta$, and possibly MAPKs. Closely tied to the ability of EPO to maintain cellular integrity and prevent inflammatory activation that ultimately can lead to cellular apoptosis are the maintenance of $\Delta \Psi_{\mathrm{m}}$, the modulation of Apaf-1, the release of cytochrome $\mathrm{c}$ (Cyto-c) and the activation of caspases 1, 3, 8 and 9.

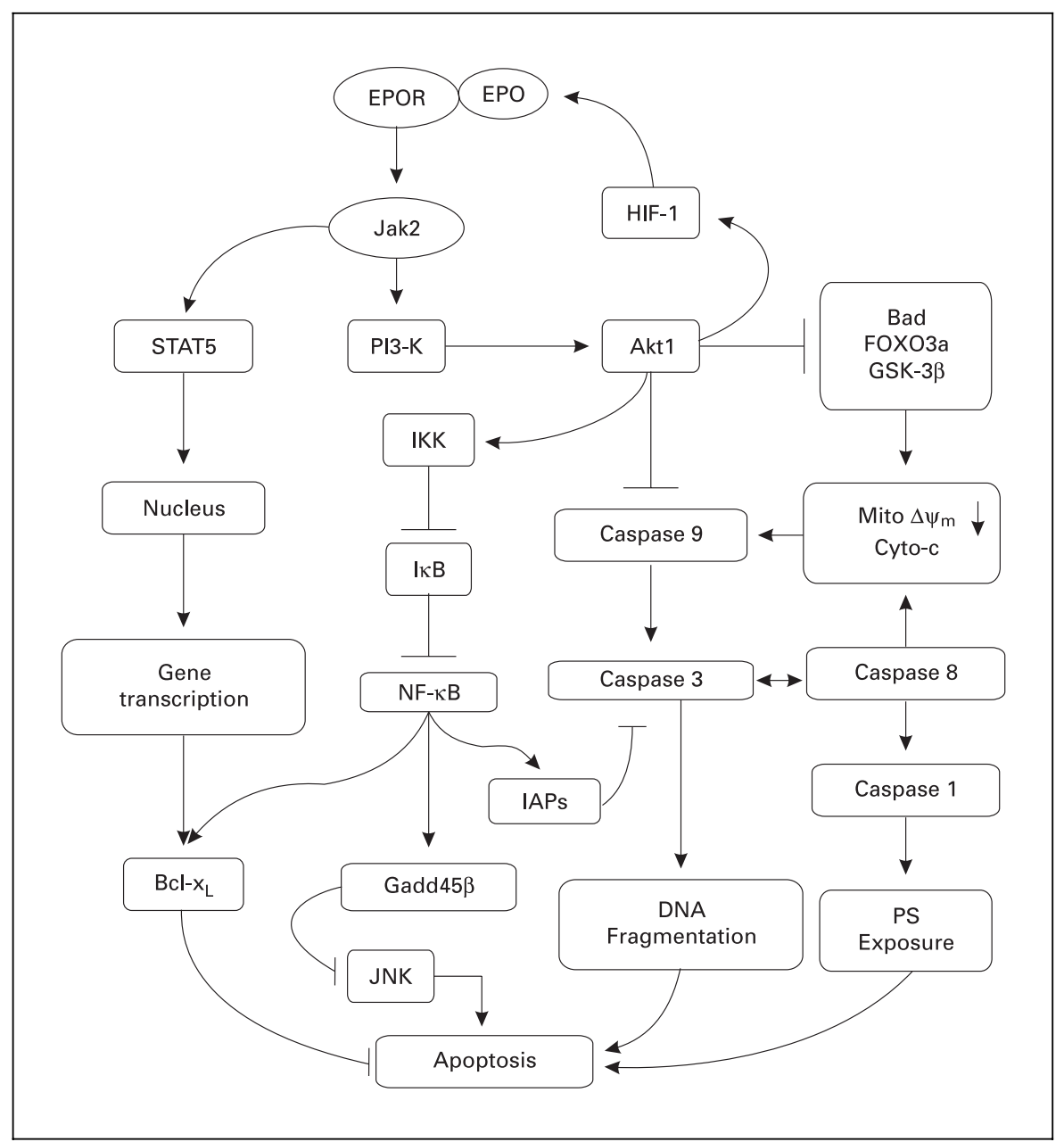

microglial activation has been observed to occur in concert with the evolution of amyloid plaques [117].

Recently, EPO has been demonstrated to reduce or prevent cellular inflammation during oxidative stress [106, 118], cerebral ischemia [119], and trauma [61]. The protein Akt can modulate the spatial regulation of actin assembly, suggesting a relationship between Akt and the coordination of cytoskeletal organization [120]. In addition, Akt appears to be a necessary component for the modulation of membrane PS externalization and prevent microglial activation [102, 106, 107, 118] (fig. 2). Recent work also has shown that Akt can directly control cellular membrane asymmetry and microglial activation through the prevention of cysteine protease degradation of Bcl- $\mathrm{x}_{\mathrm{L}}$ and the specific inhibition of caspase 1-, 3- and 9-like activities [121] (fig. 2). EPO can control microglial activation through the modulation of Akt and cellular mem- brane PS exposure [27, 118]. As a result, the shedding of membrane PS residues that is known to occur during apoptosis may be prevented [122]. Prevention of inflammatory microglial activation by EPO also may be dependent upon caspase activation and cytokine release. EPO can directly inhibit the activities of caspase 1, 3, 8 and 9 . Caspase 1 is believed to be principally responsible for the externalization of membrane PS residues in several cell populations and required for microglial activation [27, $106,118]$. EPO also may directly address cellular inflammation by blocking the release of several proinflammatory cytokines, such as IL-6, TNF- $\alpha$ and monocyte chemoattractant protein 1 [23]. 


\section{EPO and Apoptotic Oxidative Stress}

Protection against oxidative stress by EPO can be quite robust and involves preventing apoptosis from a number of sources, such as reduced or absent oxygen tension, excitotoxicity, and free radical exposure. For example, during hypoxia or glutamate exposure, administration of EPO can result in a significant increase in neuronal survival in cultured hippocampal neurons $[118,123]$. Several other studies have demonstrated that EPO elicits cellular protection against $\mathrm{NO}$ exposure and endothelial NO production to maintain blood-brain barrier integrity $[58,67,106$, $118,124]$.

Apoptosis is a primary component of cellular injury in neuronal, vascular, and cardiac cell populations. Apoptotic injury is believed to contribute significantly to a variety of neurological disorders such as ischemic stroke [104, 125], dementia [126], Alzheimer's disease [127], Parkinson's disease [128], and spinal cord injury [129, 130]. Circumstances such as the lack of trophic support, exposure to neurotoxins, and the induction of oxidative stress and DNA damage can become critical for the initiation of apoptosis [131].

EPO offers cellular protection at the levels of DNA degradation and membrane PS exposure. Membrane PS exposure and DNA fragmentation are two functionally independent processes that lead to apoptotic cellular injury. The biological role of membrane PS externalization can vary in different cell populations. In many cell systems, membrane PS externalization can become a signal for the phagocytosis of cells $[102,103,106,132]$. In the nervous system, cells expressing externalized PS may be removed by microglia. An additional role of membrane PS externalization in the vascular cell system is the activation of coagulation cascades. The externalization of membrane PS residues in ECs can promote the formation of a procoagulant surface $[100,101,133]$. In contrast to the early externalization of membrane PS residues, the cleavage of genomic DNA into fragments is a delayed event that occurs late during apoptosis [101, 134]. Application of EPO during injury can prevent the exposure of membrane PS residues and also inhibit the committed stages of genomic DNA destruction $[64,65,69,106,118]$. Thus, EPO offers early cellular protection by maintaining genomic stability and also provides a more long-term protection by maintaining membrane PS asymmetry to block microglial phagocytosis and prevent the formation of a procoagulant surface in ECs [102, 109] (fig. 2).

Posttreatment paradigms visualized in 'real time' with living cellular systems also have demonstrated a 'window of opportunity' to prevent early apoptotic changes and the progression of membrane PS residue exposure once an injury has been initiated [105, 132, 135]. Several studies that have examined the efficacy of cytoprotectants have supported the premise that cellular apoptosis is reversible. For example, the application of growth factors [136], benzothiazole compounds [137-139], metabotropic glutamate receptor agonists [104, 140], and enhanced Bcl-2 expression [141] have been shown to either prevent or reverse membrane and nuclear changes associated with apoptosis. As a result, the cellular mediators that are responsible for the induction of PS exposure and DNA fragmentation may function as critical targets for cytoprotective strategies. In this regard, the protective capacity of EPO is complex in nature and appears to require a 'therapeutic window' following the onset of a toxic exposure. This confined period for protection by EPO, which can vary up to $6 \mathrm{~h}$ in some models, most likely coincides with the progressive induction of secondary cellular pathways such as cytochrome $\mathrm{c}$ release and cysteine protease induction $[21,25]$. Several other factors may determine both the concentration and temporal parameters that regulate the protective ability of EPO, since chronic administration of EPO can result in the formation of anti-EPO antibodies [142] and decrease the expression of the EPOR on the cell surface [143].

\section{EPO and the Modulation of Cellular Pathways}

An important requirement to achieve the goal of preventing or even reducing cellular injury by any cytoprotective agent in either neuronal or vascular systems is the ability to uncover the cellular pathways that ultimately drive a cell to its demise. Recent work for EPO has begun to focus on mechanisms that involve a host of cellular signal transduction pathways. In the following sections, we present for consideration novel cellular pathways that originate from Janus kinase 2 (Jak2) and the serinethreonine kinase Akt and involve cellular pathways related to phagocytic microglia, FOXO3a, glycogen synthase kinase-3 $\beta$ (GSK-3 $\beta$ ), Bad, Bcl- $x_{L}$, nuclear factor $\kappa B$ (NF$\kappa \mathrm{B})$, mitochondrial permeability, apoptotic protease-activating factor-1 (Apaf-1), and caspases. These cellular pathways continue to shape our understanding of the significant role EPO plays that appears to be almost exclusive of its originally described function to stimulate erythropoiesis (fig. 2). 


\section{EPO Is Dependent upon Jak2 Activity and Its}

\section{Substrates}

Of course, cellular signal transduction initiated by EPO begins with the activation of the EPOR. The EPOR is part of the type 1 superfamily of cytokine receptors and is activated via homodimerization [144, 145]. Members of this receptor family share a common domain structure consisting of an extracellular ligand-binding domain, a transmembrane domain, and an intracellular domain. The extracellular domain is necessary for the initial binding of EPO and the intracellular domain is responsible for the transduction of intracellular signaling [146]. The cytoplasmic portion of the EPOR contains a Box 1 motif that specifically binds to and activates Jak 2 through phosphorylation [147].

EPO can block apoptotic injury through phosphorylation of Jak2. Jak2 is a member of a family of Janus-type protein-tyrosine kinases including Jak1, Jak2, Jak3, and Tyk 2 that are characterized by a kinase domain in the carboxyl terminal region, a kinase-like domain, and a large amino-terminal domain [148]. The amino-terminal domain of Jak2 is responsible for the binding of Jak2 with the $\beta$-subunit of the EPOR at a region proximal to the membrane that contains Box 1 sequence [149]. EPO appears to prevent neuronal cell apoptotic injury through its reliance on Jak2 phosphorylation [150], since a loss of Jak2 activity abrogates the cytoprotection by EPO [151]. As a result of an increased Jak2 phosphorylation, EPO also can reduce peripheral pain sensation [65].

The signal transducer and activator of transcription (STAT) proteins are direct substrates of Janus kinases. Activation of Jak kinases results in tyrosine phosphorylation and dimerization of STATs. The active STATs then translocate to the nucleus and bind to specific DNA sequences in the promoter regions of responsive genes to lead to gene transcription. Six primary mammalian STAT genes have been identified. They consist of STAT1, 2, 3, 4, 5 and 6 and are essential for performing pleiotropic cellular functions in response to cytokines and growth factors.

Activation of STAT 5 also can modulate EPO proliferation as well as protection against cellular apoptosis [152]. In erythroleukemic cell lines, EPO-dependent cell survival is accompanied by sustained STAT5 DNA-binding activity. Stable expression of the truncated STAT5a has been shown to enhance STAT5-DNA binding activity and reduce the induction of apoptosis [153]. In contrast, induction of apoptosis can be observed in cells that lack STAT5 (STAT5a $\mathrm{a}^{-/} / 5 \mathrm{~b}^{-/-}$) function [154]. For example, STAT $5 \mathrm{a}^{-/-5 b^{-/}}$fetal liver erythroid progenitors show higher levels of apoptosis and are less responsive to the presence of EPO [155].

\section{Activation of Protein Kinase B (Akt) Promotes Cellular} Survival through EPO

In addition to Jak2, EPO is dependent upon the activation of phosphoinositide 3-kinase (PI 3-K) and protein kinase B (PKB), also known as Akt [156]. Akt has been identified as a principal component in a variety of pathways to promote cell survival and block apoptotic degradation. In mammals, three family members of PKB have been identified, which are termed $\mathrm{PKB} \alpha$ or Akt1, $\mathrm{PKB} \beta$ or Akt2, and PKB $\gamma$ or Akt3. Akt belongs to the cAMPdependent kinase/protein kinase $\mathrm{G} /$ protein kinase $\mathrm{C}$ (PKC) superfamily of protein kinases and consists of three functionally domains $[157,158]$. The N-terminal pleckstrin homology $(\mathrm{PH})$ domain provides binding sites for membrane phospholipids, which is involved in the recruitment of Akt to the plasma membrane. The catalytic domain of Akt has specificity for serine or threonine residues of several Akt substrates. The C-terminal hydrophobic motif functions to provide a docking site for the activation of kinases.

Expression for Akt1 and Akt2 is present at high levels in the brain during development, but gradually is decreased during postnatal periods [159]. Following stimulation by agents such as trophic factors or cytokines, PI $3-\mathrm{K}$ is recruited to the plasma membrane, phosphorylates glycerophospholipid phosphatidylinositol 4,5-bisphosphate, and results in the production of phosphatidylinositol 3,4-bisphosphate $\left(\mathrm{PIP}_{2}\right)$ and phosphatidylinositol 3,4,5-trisphosphate $\left(\mathrm{PIP}_{3}\right)$. Akt then translocates from the cytosol to the cell membrane after its binding to $\mathrm{PIP}_{2}$ and $\mathrm{PIP}_{3}$ through their respective $\mathrm{PH}$ domains, and subsequently becomes activated through phosphorylation by phosphoinositide-dependent kinase 1 [160].

Once activated, Akt can provide protection against cellular injury. Maximal activity of Akt is achieved through phosphorylation by phosphoinositide-dependent kinase 1 at $\mathrm{Ser}^{473}$ to confer protection against genomic DNA degradation $[69,161,162]$ and membrane PS exposure [69, $102,106]$. During a number of injury paradigms, such as toxic insults involving excitotoxicity [163], free radical exposure [106, 121, 164], neuronal axotomy [165], hypoxia [69], or trauma [166], Akt is phosphorylated leading to increased activity and protection against apoptosis induction.

EPO elicits phosphorylation of Akt and this is dependent upon the activation of PI 3-K and Jak2 [156]. The phosphorylation of two residues, $\mathrm{Thr}^{308}$ and $\mathrm{Ser}^{473}$, is con- 
sidered necessary for the activation of Akt [167]. Activation of Jak 2 promotes the phosphorylation of tyrosine residues in the intracellular portion of the EPOR [147]. Phosphorylation of the last tyrosine of the EPOR initiates binding of the $85-\mathrm{kDa}$ regulatory subunit of PI 3-K, a heterodimer consisting of a $110-\mathrm{kDa}$ catalytic subunit and an $85-\mathrm{kDa}$ regulatory subunit. As a result of the binding of the $85-\mathrm{kDa}$ regulatory subunit, the $110-\mathrm{kDa}$ catalytic subunit becomes active and leads to the phosphorylation of Akt [168].

Central to the ability of EPO to prevent cellular apoptosis is the activation of Akt by EPO. In primary human erythroid progenitors, apoptosis is blocked through the activation of Akt [169]. During anoxia or free radical exposure, expression of the active form of Akt (phospho$\mathrm{Akt}$ ) is increased $[102,107]$. EPO can significantly enhance the activity of Akt during oxidative stress and prevent inflammatory activation of microglia [27, 106, 118]. This upregulation of Akt activity during injury paradigms appears to be vital for EPO protection, since prevention of Akt phosphorylation blocks cellular protection by EPO $[27,106,118]$. Through the regulation of the PI 3-K/Aktdependent pathway, EPO can prevent cellular apoptosis following $\mathrm{N}$-methyl- $D$-aspartate toxicity [170], neuronal axotomy [165], hypoxia [69], and oxidative stress [27, $106,118]$

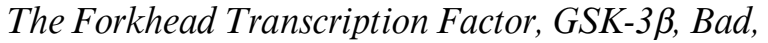 $B c l-x_{L}$, and NF- $\kappa B$ Are Essential for EPO to Afford Cellular Protection}

The forkhead transcription factor (FOXO3a, FKHRL1) represents one cellular pathway that is centrally controlled by Akt. Activation of FOXO3a can result in apoptotic cellular degeneration in a transcription-dependent manner following its translocation to the nucleus [171-173]. FOXO3a activation has been demonstrated to disrupt mitochondrial membrane permeability $\left(\Delta \Psi_{\mathrm{m}}\right)$ and may result in cytochrome c release [174]. Akt inhibition of FOXO3a requires its phosphorylation that results in the association of FOXO3a with 14-3-3 protein and retention of FOXO3a in the cytoplasm, rendering it ineffective in regulating nuclear genes, resulting in the blockade of apoptosis. During periods of oxidative stress in the nervous system, an initial inhibitory phosphorylation of FOXO3a at the regulatory phosphorylation sites $\left(\mathrm{Thr}^{32}\right.$ and $\operatorname{Ser}^{253}$ ) can occur $[173,175,176]$. However, loss of phosphorylated FOXO3a expression appears to subsequently result over a 12-hour period, possibly by caspase degradation, which potentially can enhance the vulnerability of cells to apoptotic injury [176]. EPO may function to prevent apoptotic injury, possibly through an Aktdependent mechanism, by preventing the association of FOXO3a with the transcriptional coactivator $\mathrm{p} 300$ that would normally lead to the induction of apoptosis [177].

Akt also regulates the activity of GSK-3 $\beta$, a serine/ threonine kinase. Although phosphorylation of GSK-3 $\beta$ at $\operatorname{Ser}^{9}$ by Akt results in its inactivation, it is important to note that phosphorylation of GSK-3 $\beta$ at $\mathrm{Thr}^{216}$ results in an enhanced activity of the enzyme, which can occur during neuronal degeneration [178]. GSK-3 $\beta$ plays a significant role in the regulation of apoptosis in several cell types, such as neurons [179], vascular smooth muscle cells [180], and cardiomyocytes [181]. For example, GSK-3 $\beta$ has been shown to be involved with the neurotoxicity of $\mathrm{A} \beta$ during Alzheimer's disease and its expression coincides with the development of neurofibrillary changes [182]. GSK-3 $\beta$ also can regulate amyloid precursor protein (APP) processing and the phosphorylation of tau $[131,135]$. GSK-3 $\beta$ facilitates $A \beta$ release by increasing the cellular maturation of APP [183], a process believed to occur during the early onset of Alzheimer's disease [184]. Although overexpression of GSK-3 $\beta$ can trigger apoptosis possibly through the transcription factors cAMP response element binding protein, c-myc, c-jun, and $\beta$-catenin, inhibition of GSK-3 $\beta$ activity by Akt can prevent cell injury. In regard to EPO, GSK-3 $\beta$ activity is suppressed by EPO and may be associated with a conformational change in Bax to prevent cell death [185].

Akt can inactivate Bad, a proapoptotic Bcl-2 family member, through phosphorylation of its serine residues. Bad is a Bcl-2 homology 3 (BH3)-only subfamily member of Bcl-2 proteins that are associated with the regulation of apoptosis. Three phosphorylated serine sites have been identified on Bad, including Ser ${ }^{112}$, Ser ${ }^{136}$, and Ser ${ }^{155}$. Akt preferentially phosphorylates the residue $\mathrm{Ser}^{136}$ of Bad [186]. A fourth phosphorylation site of Bad has recently been identified at $\operatorname{Ser}^{170}$ that also results in the blockade of proapoptotic activity of $\mathrm{Bad}$ [187]. The endogenous dephosphorylated Bad is localized in the outer mitochondrial membrane and binds to the antiapoptotic Bcl-2 family member Bcl- $\mathrm{x}_{\mathrm{L}}$ through its BH3 domain. Subsequent phosphorylation of Bad by Akt leads to the binding of Bad with the cytosolic protein 14-3-3 to release Bcl- $\mathrm{x}_{\mathrm{L}}$ and allow it to block apoptosis. Bcl-2 and Bcl- $\mathrm{x}_{\mathrm{L}}$ prevent Bax translocation to the mitochondria, maintain the potential of the mitochondrial membrane, and prevent the release of cytochrome $\mathrm{c}$ from the mitochondria [188].

EPO is linked to Bad and the Bcl-2 family through Bcl$\mathrm{x}_{\mathrm{L}}$. In erythroid cells, the $\mathrm{Bcl}-2$ member $\mathrm{Bcl}-\mathrm{x}_{\mathrm{L}}$ has been shown to be strongly expressed and necessary for EPO to 
prevent apoptosis in the later stages of erythroid progenitor cell life [189]. In addition, expression of Bcl-2 and Bcl$\mathrm{x}_{\mathrm{L}}$ has been demonstrated to be dependent upon EPO. For example, in a murine erythroid progenitor cell line, EPO can specifically maintain the expression of Bcl-2 and Bcl$\mathrm{x}_{\mathrm{L}}$ [190]. EPO also is able to maintain the expression of $\mathrm{Bcl}-2$ and $\mathrm{Bcl}-\mathrm{x}_{\mathrm{L}}$ and alter the $\mathrm{Bcl} / \mathrm{Bax}$ ratio towards a net 'antiapoptotic' effect, thereby preventing cellular injury [191]. EPO may require Bcl- $\mathrm{x}_{\mathrm{L}}$ expression for cytoprotection, since without EPO, Bcl- $\mathrm{x}_{\mathrm{L}}$ is not expressed and apoptotic cell death results in hematopoietic cells [190]. Similar results in neurons and ECs illustrate that upregulation of Bcl- $\mathrm{x}_{\mathrm{L}}$ by EPO may be necessary for the prevention of apoptosis [27] in combination with the modulation of Apaf-1 expression and cytochrome c release, similar to other 'antiapoptotic' proteins, such as heat shock proteins [192-194].

Expression and cytoprotection of EPO also are dependent, in part, upon Akt and the activation of NF- $\kappa B$. The induction of several antiapoptotic genes by NF-кB accounts for its cytoprotective action. NF-KB has been shown to induce the expression of the inhibitors of apoptotic protein (IAPs) c-IAP1, c-IAP2, and x-chromosomelinked IAP. IAPs can specifically inhibit active forms of caspase 3, 7 and 9 [195]. Induction of IAP 1 and c-IAP2 by NF- $\kappa \mathrm{B}$ also suppresses TNF- $\alpha$ initiated apoptosis through the inhibition of caspase 8 activation [196]. In addition, xIAP activation by NF- $\mathrm{KB}$ is associated with the downregulation of JNK [197]. Growth arrest and DNA damage protein $45(\mathrm{Gadd} 45 \beta)$ also has been identified as another downstream target of NF- $\kappa B$. Gadd $45 \beta$ is a member of the Gadd45 family associated with cell cycle and DNA repair [198]. The induction of Gadd $45 \beta$ protein by TNF- $\alpha$ is NF- $\kappa B$ dependent and responsible for the downregulation of JNK activation and suppression of apoptosis [199]. NF-KB also may prevent apoptosis through the direct activation of Bcl- $\mathrm{x}_{\mathrm{L}}$ [200].

NF- $\kappa B$ plays a key role in the induction of EPO during HIF-1 induction. Akt can significantly increase NF- $\mathrm{kB}$ and HIF-1 activation resulting in the enhancement of EPO expression [201]. Through a regulatory loop, EPO also can promote IKB kinase (IKK) activity, resulting in the degradation of $\mathrm{I} \kappa \mathrm{B}$ and the subsequent liberation of $\mathrm{NF}-\kappa \mathrm{B}$. EPO may require NF- $\kappa \mathrm{B}$ activation to foster the production of neural stem cells [52] and prevent neuronal apoptosis [202].

\section{Modulation of Mitochondrial Membrane Permeability through EPO}

Cytoprotection by EPO is closely related to the maintenance of mitochondrial membrane potential $\left(\Delta \Psi_{\mathrm{m}}\right)$. Loss of $\Delta \Psi_{\mathrm{m}}$ through the opening of the mitochondrial permeability transition pore represents a significant determinant for cell injury and the subsequent induction of apoptosis $[27,203,204]$. Studies that involve free radical injury, anoxia, or oxygen-glucose deprivation demonstrate that EPO prevents the depolarization of the mitochondrial membrane by maintaining $\Delta \Psi_{\mathrm{m}}$ and preventing the release of cytochrome c $[69,102,205]$. Yet, EPO also may maintain $\Delta \Psi_{\mathrm{m}}$ by activating Akt and regulating caspasemediated pathways. EPO appears to employ Akt to prevent apoptosis at either a pre- or a postmitochondrial level. At a premitochondrial level, Akt can directly prevent the activation of caspase 9 [20,27]. At a postmitochondrial level, Akt can inhibit the release of cytochrome c from mitochondria and block both caspase 9 and caspase 3 activity [205]. Feedback of these systems also can exist that modulates the half-life of Akt. Activity of Akt can be eliminated by caspase 3 induction, since caspase 3 has been shown to cleave Akt leading to the inhibition of Akt kinase activity [206].

\section{EPO Can Oversee the Execution of Cells through Modulation of Caspase Activity}

Intimately associated with the disruption in $\Delta \Psi_{\mathrm{m}}$ during neuronal and vascular injury is the induction of caspase activity. Caspases are a family of cysteine proteases that cleave their substrates after aspartic residues. They are usually synthesized as inactive zymogens that are proteolytically cleaved into subunits at the onset of apoptosis and function as active caspases after reconstitution to molecular heterodimers. Caspases are composed of three domains including an N-terminal prodomain, a large subunit, and a small subunit [207]. As a result of their activation sequence, caspases are classified as either initiator caspases (also known as apical caspases) or effector caspases [208]. An initiator caspase cleaves and subsequently activates an effector caspase. The apoptotic-associated caspases include initiator caspases, such as caspase 2, 8, 9 and 10, that activate downstream effector caspases, resulting in an amplification of cascade activity. The initiator caspases consist of long $\mathrm{N}$-terminal prodomains that contain caspase recruitment domains (CARDs) in caspase 2 and caspase 9, or death effector domains (DEDs) in caspase 8 and caspase 10 [209]. The effector caspases consist of caspase 3, 6 and 7 that function to directly cleave crucial cellular protein substrates that result in cell destruc-

\footnotetext{
$\overline{278} \quad \overline{\text { Neurosignals 2004;13:265-289 }}$
} 
tion. The effector caspases contain short prodomains or have no prodomains.

Activation of caspases proceeds through extrinsic and intrinsic pathways. The extrinsic pathway is initiated by death receptor activation at the cell surface, resulting in the recruitment and activation of the initiator caspase 8 upon apoptotic stimuli [210]. The intracellular death domain of death receptors, such as the TNF superfamily, CD95/Fas/Apo-1, and the death receptor 3, undergoes conformational change upon binding to extracellular ligands and forms an intracellular death-inducing signaling complex following recruitment of adaptor molecules, such as the Fas-associated death domain (FADD). FADD recruits caspase 8 through its DED domain and this leads to caspase 8 activation $[211,212]$. Caspase 8 can subsequently activate caspase 3 . In addition, caspase 8 activation also may result in the cleavage of Bid, a proapoptotic member of Bcl-2 family, allowing the truncated Bid (tBid) to translocate to the mitochondria [213]. This leads to cytochrome $\mathrm{c}$ release through Bax resulting in the subsequent activation of executioner caspases [214].

The intrinsic caspase pathway involves mitochondrial dysfunction. The mitochondrial pathway is associated with the release of cytochrome $\mathrm{c}$ and subsequent activation of caspase 9 followed by activation of caspase 3 [215]. The process is regulated by the Bcl-2 subfamily BH3-only proteins, which are normally located in cellular compartments other than mitochondria, but translocate to the mitochondria in response to apoptotic stimuli [216]. The translocation of these proteins delivers an apoptotic signal to mitochondria through the interaction with Bax to induce the release of cytochrome $\mathrm{c}$ that then binds to Apaf-1. Apaf-1 consists of three different domains that include CARDs, repeats of tryptophan and aspartate residues (WD-40 repeats), and a nucleotide-binding domain CED-4. Binding of cytochrome $\mathrm{c}$ to Apaf-1 results in the removal of the WD-40 domain, masking the CED-4 and CARDs, and leads to the oligomerization of Apaf-1 with the requirement of dATP/ATP [217]. The oligomerization of Apaf-1 promotes the allosteric activation of caspase 9 by forming the Apaf- 1 apoptosome [218]. Caspase 9 can subsequently activate caspase 3 [218] as well as caspase 1 through the intermediary caspase 8 [219]. Together, caspase 1 and caspase 3 lead to both DNA fragmentation and membrane PS exposure [69, 101, 218].

Modulation of caspase activation by EPO may offer several avenues for protection against cell injury. The ability of EPO to prevent specific caspase 1- and caspase 3 -like activities appears to play a significant role in its cellular protection $[27,69,88]$. The caspases 1 and 3 have each been linked to the independent apoptotic pathways of genomic DNA cleavage and cellular membrane PS exposure $[27,118,219]$. With respect to caspase 1, EPO prevents PS externalization primarily through the inhibition of caspase 1-like activity and, to a lesser degree, through other caspases such as 3, 8 and 9 [27, 69, 106, 118]. These caspases are also tied to the direct activation and proliferation of microglia [102, 106, 107]. Caspase 1 is believed to be principally responsible for the externalization of membrane PS residues in several cell systems that can subsequently activate microglial phagocytosis $[101,220]$.

EPO may prevent genomic DNA degradation through the inhibition of cytochrome $\mathrm{c}$ and the subsequent blockade of caspase 3-like activity [106]. Modulation of caspase 3-like activity by EPO also may be linked to a unique regulatory mechanism that blocks the proteolytic degradation of phosphorylated FOXO3a by caspase 3. Given that FOXO3a has been shown to be a substrate for caspase 3-like proteases at the consensus sequence $\mathrm{DELD}^{304} \mathrm{~A}$ [221], current work demonstrates that blockade of caspase 3-like activity prevents the destruction of phosphorylated FOXO3a during oxidative stress [176]. In light of the ability of EPO to directly inhibit caspase 3-like activity [20, $69,118]$ and maintain inhibitory phosphorylation of FOXO3a [177], EPO may control FOXO3a through caspase 3.

In addition to preventing the activation of caspase 1 and caspase 3, EPO also can prevent caspase 8 and caspase 9-like activities [27, 118]. Caspase 9 is activated through a process that involves the cytochrome c-Apaf-1 complex [62, 218]. Interestingly, EPO can prevent cell injury by inhibiting caspase 9-like activity either through Apaf-1 or directly [27]. In addition, caspase 8 serves as an upstream initiator of executioner caspases, such as caspase 3 , and also leads to the mitochondrial release of cytochrome c [222, 223]. Following caspase 8 and caspase 9 activation, caspase 3 directly leads to genomic DNA degradation. EPO prevents cellular apoptosis through parallel pathways that prevent the induction of Apaf- 1 and preserve mitochondrial membrane potential in conjunction with enhanced Bcl- $x_{L}$ expression [27]. Consistent with the modulation of Apaf-1 and the release of cytochrome c, EPO inhibits the activation of caspase 9 and caspase 3like activities [27]. Therefore, EPO functions at both intrinsic and extrinsic pathways to prevent caspase activation and promote cellular integrity with maintenance of membrane PS asymmetry.

Neurosignals 2004;13:265-289 279 


\section{Phosphorylation of the Mitogen-Activated Protein \\ Kinases by EPO}

The mitogen-activated protein kinases (MAPKs) are serine/threonine kinases that include the extracellular signal-related kinases (ERKs), the c-Jun amino-terminal kinases (JNKs), and p38 MAP kinase (p38). These kinases usually represent the terminal stages of signaling cascades that are activated by survival factors or death promoting receptors. Following activation, the MAPKs translocate to the cell nucleus to activate transcription activity and modulate cell differentiation, growth, or death. The ERK pathway is primarily associated with the regulation of apoptosis and can be cytoprotective, especially through activity of the ERK1/2 pathway [224, 225]. JNK and p38 activation has been associated with the induction of apoptosis during growth factor deprivation [226] and inflammatory cytokine application [227]. In neuronal and EC cultures subjected to oxidative stress, phosphorylation of $\mathrm{p} 38$ and JNK has been linked to apoptotic injury [20, 228, 229].

The phosphorylation of MAPKs may contribute to the cytoprotection offered by EPO. EPO can phosphorylate ERKs [230] and increase the activity of JNK and p38 [231]. This enhancement of JNK and p38 activity is believed to mediate both erythroid proliferation and differentiation [232]. Yet, modulation of JNK and p38 activity by EPO may be cell specific. In several cell systems during toxic insults, protection by EPO does not appear to require the phosphorylation of $\mathrm{p} 38$ or JNK, suggesting that cellular protection by EPO against apoptosis may be independent of the modulation of p38 and JNK activity [204, 231, 233].

\section{EPO Is Closely Tied to PKC and Cellular Calcium Homeostasis}

The PKC family contains eleven PKC isoenzymes that consist of three groups that can modulate apoptosis. The classical (PKC- $\alpha, \beta_{\mathrm{I}}, \beta_{\mathrm{II}}$, and $\gamma$ ) and atypical (PKC- $\zeta, \mu$, $\checkmark / \lambda$ ) groups are associated with the inhibition of apoptosis and cell survival. In contrast, the novel PKC isoenzymes $(\delta, \eta, \varepsilon$ and $\theta)$ are proapoptotic in function [234, 235]. The classical or 'calcium-dependent' isoenzymes require calcium for activation, while the novel and atypical types are calcium independent. PKC- $\alpha$ is the best-characterized antiapoptotic isoenzyme and has been shown to exert its apoptosis-inhibiting effects through the phosphorylation of Bcl-2 [236].

PKC is involved in the signal transduction pathways of EPO. PKC regulates erythroid proliferation and differentiation that is initiated by EPO. PKC- $\alpha$ has been identified as the only calcium-dependent PKC subtype ex- pressed in erythroid progenitors. The PKC- $\alpha$ isoform also functions in mediating EPO-induced erythroid differentiation of CD34(+) progenitor cells [237]. Furthermore, inhibition of PKC activity also interferes with the phosphorylation of the EPOR, suggesting that PKC may function as an upstream modulator of the EPOR [238]. Investigations in myocardial ischemia further suggest that PKC is a necessary component for protection in the cardiovascular system since recovery of left and right ventricular developed pressure during EPO administration is abrogated by inhibition of PKC activity [239].

Given that the classical PKC isoenzymes are calcium dependent for activity, it is reasonable to assume that EPO may be involved in the modulation of cellular calcium homeostasis. Early work has demonstrated that EPO can elicit a rapid increase in intracellular free calcium in human bone marrow mononuclear cells [240]. Recent patch-clamp studies have shown that EPO can stimulate the activity of T-type voltage-dependent calcium channels [241]. EPO also can directly enhance intracellular calcium and monoamine concentrations in pheochromocytoma neuronal cell lines [242]. This work suggests that EPO can influence calcium homeostasis through either an increase in calcium influx via plasma membrane T-type voltage-dependent calcium channels or through extracellular sources [123, 243]. A rapid transient increase in $\left[\mathrm{Ca}^{2+}\right]_{\mathrm{i}}$ concentration by EPO may be necessary for cytoprotection during excitotoxicity, since a decrease in intracellular calcium can negate any protection by EPO during glutamate administration [123]. EPO may promote neuronal viability by enhancing the cytosolic concentration of free calcium and inducing cell membrane depolarization as a result of the activation of calcium channels [242, 244]. This increased function and viability of neurons through a potential calcium mechanism by EPO has been suggested to be linked to enhanced NO generation [244]. Such observations concerning a potential synergistic function for cellular protection that require $\left[\mathrm{Ca}^{2+}\right]_{i}$ are not unique and have been reported with other cellular receptor systems, such as those that involve $\mathrm{G}$ protein-related pathways [140, 245].

\section{EPO and Its Future for Clinical Medicine}

\section{Considerations of Clinical Efficacy, Safety, and Toxicity for EPO}

Given its ability to foster cell survival in multiple biological systems, EPO should be considered as a novel clinical agent ripe for the development as robust and effica- 
cious therapy for an array of disorders. Cytoprotective agents that can provide both safe and efficacious treatment would be considered extremely attractive, especially in the neuroscience and cardiovascular arenas. In this light, EPO appears to fill such a role as a nontoxic cytoprotective agent. Years of clinical administration in the patients with anemia and chronic kidney diseases have shown EPO to be well tolerated and safe [1]. More recently, one clinical trial has demonstrated safety for EPO in a limited number of patients with acute ischemic stroke and additional trials will seek to examine the role of EPO during neonatal ischemia and psychiatric disorders [20,21].

Yet, the clinical application of many cytoprotective agents has been hampered by subsequent evidence of clinical toxicity and unfortunately EPO is not exempt from this issue. Adverse effects in patients receiving EPO for approved indications have been reported. Usually, toxic effects occurring after EPO administration are related to associated disease states, such as chronic renal failure, cancer, human immunodeficiency viral infection, or sequela following surgery [246]. Yet, both acute and longterm administration of EPO can precipitate hypertensive emergencies. As a result, the use of EPO in patients with uncontrolled hypertension is contraindicated [247].

Several mechanisms have been proposed to account for the elevation in vascular resistance and the subsequent development of high blood pressure during EPO administration. Early studies recognized that increased blood viscosity as a result of rising hematocrit values contributed to high blood pressure during chronic treatment with EPO [248]. The correction of anemia by EPO resulted in an increase in erythrocyte mass and blood viscosity [249] and the reversal of hypoxic vasodilation in uremic anemia [250]. Further studies demonstrated that constant dosage and chronic administration of EPO in iron-deficient renal anemic patients did not increase blood pressure despite a dramatic increase in hematocrit by iron repletion [251]. Thus, EPO can lead to hypertension during chronic treatment that appears to be independent of hematocrit levels.

Changes in vasoactive substances also may contribute to the hypertensive effect of EPO. Treatment with EPO enhances vascular responsiveness to norepinephrine in renal failure [252] without an alteration of plasma catecholamine levels [253]. Further experiments that demonstrate an increase in $\left[\mathrm{Ca}^{2+}\right]_{\mathrm{i}}$ in vascular smooth muscle during EPO administration suggest that calcium mobilization also may contribute to the hypertension associated with rhEPO treatment [254]. In addition, EPO may impair the balance between vasodilatory prostaglandin and vasoconstrictive components by reducing prostacyclin production and increasing the formation of prostaglandin $\mathrm{F}_{2 \alpha}$ and thromboxane $\mathrm{B}_{2}$ [255].

Enhanced NO production may serve to counteract the hypertension associated with EPO administration. An increase in NO production together with hypertension has been observed during EPO treatment in rats, suggesting that impairment of endogenous NO activity is not responsible for EPO-associated hypertension. More likely, endogenous NO activity may function as a mechanism that limits the hypertensive effect of EPO [256]. This hypothesis is supported by the observation that an NO synthase inhibitor can abolish renal vasodilation and result in hypertension during treatment with EPO in rats [257]. Other reports illustrate that EPO therapy can impair the vasodilatory response to NO donor sodium nitroprusside and S-nitroso-N-acetyl- $D, L$-penicillamine in chronic renal failure in rats [258]. Investigations into the mechanisms underlying vasodilatory resistance to $\mathrm{NO}$ found that treatment with EPO raised resting $\left[\mathrm{Ca}^{2+}\right]_{i}$ in rats with chronic renal failure [259]. The concurrent administration of the calcium channel blocker felodipine normalized resting $\left[\mathrm{Ca}^{2+}\right]_{\mathrm{i}}$, increased NO production, and abolished hypertension induced by EPO. These results suggest that an elevation of $\left[\mathrm{Ca}^{2+}\right]_{\mathrm{i}}$ by EPO may explain an impaired vasodilatory response during the presence of NO.

Depending on the specific disease entity, administration of EPO can lead to other disabilities. EPO can result in the formation of anti-EPO antibodies, red cell aplasia [142], and decrease the expression of the EPOR on the cell surface [143], setting the stage for a vicious cycle of increased administration of EPO with the subsequent occurrence of increased toxic side effects. Maintenance treatment with EPO also has been associated with nonfatal myocardial infarction, vascular thrombosis, pyrexia, vomiting, shortness of breath, paresthesias, and upper respiratory tract infection [246].

In regard to nervous system and cardiovascular applications, development of toxic side effects during EPO therapy, such as for cerebral ischemia [260], could severely limit or halt the use of EPO for diseases of the nervous system. Therefore, strategies have been suggested to develop derivations of EPO, such as asialo-EPO and neurotrophic sequences of EPO [230], to remove erythropoietic activity and potential toxicity. Yet, present work on such approaches suggests that derivatives of EPO may possess only limited utility [261] and lack the ability to promote angiogenesis which could be critical for cytoprotection, prompting the need for further investigations $[25,35$, 69]. 


\section{EPO: Clinical Development on a Tightrope}

Current investigations have suggested a new therapeutic potential for EPO as a cellular protectant and an antiinflammatory mediator, rather than as an agent necessary only for the induction of erythropoiesis. EPO can prevent the loss of neurons, ECs, and cardiomyocytes and promote their functional recovery in acute and chronic diseases. As a cytoprotective agent, EPO may have applicability in a host of disorders that range from cerebral ischemia, Alzheimer's disease, Parkinson's disease, psychiatric disorders, and diabetic neuropathies [20, 21, 262] to disorders that impact upon cardiac function such as acute myocardial ischemia and chronic congestive heart failure [87].

Initially described as hematopoietic growth factor, but now considered to interface with a variety of biological cell functions, EPO modulates an array of vital cellular functions that involve progenitor stem cell development, cellular protection, angiogenesis, DNA repair, and cellular longevity. Cellular protection offered by EPO through the preservation of membrane PS asymmetry alters acute cellular injury as well as secondary thrombosis, clot formation, and inflammation.

EPO fosters cellular function and survival through a series of distinct pathways that involve Jak2, STATs, and the serine-threonine kinase Akt with its downstream sub-

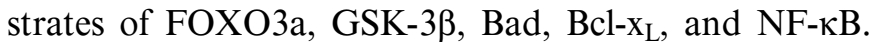
Particularly attractive is the ability of EPO to use the Akt pathway for protection of cells from inflammatory injury through the direct modulation of cellular membrane PS externalization. Intimately associated with the protective ability of EPO is the maintenance of $\Delta \Psi_{\mathrm{m}}$, the central modulation of Bax, and cytochrome c release. Ultimately, EPO is able to govern Apaf-1 as well as extrinsic and intrinsic caspase pathways to preserve genomic integrity and prevent early apoptotic loss of membrane asymmetry that can lead to microglial disposal.

New investigations must uncover the cellular mechanisms that determine whether EPO can fulfill its potential as a broad and safe cytoprotectant for multiple cell systems or ultimately leads to disability, such as with hypertensive complications or autoimmune toxicity. It is clear that the development of EPO for clinical applications rests on 'tightrope' that must be carefully negotiated with a fine balance that maximizes treatment efficacy and minimizes toxic outcomes. As our knowledge of EPO becomes more refined, we should be able to appreciate in greater depth the role that EPO plays during the development, maturation, and survival of cells not only in the nervous system, but throughout the entire body.

\section{Acknowledgments}

This research was supported by the following grants (KM): American Heart Association (National), Janssen Neuroscience Award, Johnson and Johnson Focused Investigator Award, LEARN Foundation Award, MI Life Sciences Challenge Award, and NIH NIEHS (P30 ES06639).

\section{References}

1 Jelkmann W, Metzen E: Erythropoietin in the control of red cell production. Anat Anz 1996; 178:391-403.

-2 Jacobs K, Shoemaker C, Rudersdorf R, Neill SD, Kaufman RJ, Mufson A, Seehra J, Jones SS, Hewick R, Fritsch EF, et al: Isolation and characterization of genomic and cDNA clones of human erythropoietin. Nature 1985;313: 806-810.

3 Imai N, Kawamura A, Higuchi M, Oh-eda M, Orita T, Kawaguchi T, Ochi N: Physicochemical and biological comparison of recombinant human erythropoietin with human urinary erythropoietin. J Biochem (Tokyo) 1990;107: 352-359.

$\checkmark 4$ Tsuda E, Goto M, Murakami A, Akai K, Ueda M, Kawanishi G, Takahashi N, Sasaki R, Chiba $\mathrm{H}$, Ishihara $\mathrm{H}$, et al: Comparative structural study of N-linked oligosaccharides of urinary and recombinant erythropoietins. Biochemistry 1988;27:5646-5654.
5 Sasaki Y, Sasaki Y, Kanno K, Hidaka H: Disorganization by calcium antagonists of actin microfilament in aortic smooth muscle cells. Am J Physiol 1987;253:C71-C78.

6 Toyoda T, Itai T, Arakawa T, Aoki KH, Yamaguchi $\mathrm{H}$ : Stabilization of human recombinant erythropoietin through interactions with the highly branched N-glycans. J Biochem (Tokyo) 2000;128:731-737.

7 Uchida E, Morimoto K, Kawasaki N, Izaki Y, Abdu Said A, Hayakawa T: Effect of active oxygen radicals on protein and carbohydrate moieties of recombinant human erythropoietin. Free Radic Res 1997;27:311-323.

8 Krantz SB: Erythropoietin. Blood 1991;77: 419-434.

9 Dube S, Fisher JW, Powell JS: Glycosylation at specific sites of erythropoietin is essential for biosynthesis, secretion, and biological function. J Biol Chem 1988;263:17516-17521.
10 Tsuda E, Kawanishi G, Ueda M, Masuda S, Sasaki R: The role of carbohydrate in recombinant human erythropoietin. Eur J Biochem 1990;188:405-411.

11 Wang FF, Kung CK, Goldwasser E: Some chemical properties of human erythropoietin. Endocrinology 1985;116:2286-2292.

12 Fisher JW: Erythropoietin: Physiology and pharmacology update. Exp Biol Med (Maywood) 2003;228:1-14.

13 Lacombe C, Da Silva JL, Bruneval P, Casadevall N, Camilleri JP, Bariety J, Tambourin P, Varet B: Erythropoietin: Sites of synthesis and regulation of secretion. Am J Kidney Dis 1991; 18:14-19.

14 Mujais SK, Beru N, Pullman TN, Goldwasser E: Erythropoietin is produced by tubular cells of the rat kidney. Cell Biochem Biophys 1999; 30:153-166. 
15 Davis LE, Widness JA, Brace RA: Renal and placental secretion of erythropoietin during anemia or hypoxia in the ovine fetus. Am J Obstet Gynecol 2003;189:1764-1770.

-16 Anagnostou A, Liu Z, Steiner M, Chin K, Lee ES, Kessimian N, Noguchi CT: Erythropoietin receptor $\mathrm{mRNA}$ expression in human endothelial cells. Proc Natl Acad Sci USA 1994;91: 3974-3978.

17 Ribatti D, Presta M, Vacca A, Ria R, Giuliani R, Dell'Era P, Nico B, Roncali L, Dammacco F: Human erythropoietin induces a pro-angiogenic phenotype in cultured endothelial cells and stimulates neovascularization in vivo. Blood 1999;93:2627-2636.

$\checkmark 18$ Ogilvie M, Yu X, Nicolas-Metral V, Pulido SM, Liu C, Ruegg UT, Noguchi CT: Erythropoietin stimulates proliferation and interferes with differentiation of myoblasts. J Biol Chem 2000;275:39754-39761.

19 Fenjves ES, Ochoa MS, Cabrera O, Mendez AJ, Kenyon NS, Inverardi L, Ricordi C: Human, nonhuman primate, and rat pancreatic islets express erythropoietin receptors. Transplantation 2003;75:1356-1360.

-20 Chong ZZ, Kang J, Maiese K: Erythropoietin: Cytoprotection in vascular and neuronal cells. Curr Drug Targets Cardiovas Haematol Disord 2003;3:141-154.

21 Genc S, Koroglu TF, Genc K: Erythropoietin as a novel neuroprotectant. Restor Neurol Neurosci 2004;22:105-119.

22 Sasaki R: Pleiotropic functions of erythropoietin. Intern Med 2003;42:142-149.

23 Maiese K, Faqi L, Chong ZZ: Erythropoietin in the brain: Can the promise to protect be fulfilled? Trends Pharmacol Sci, in press.

24 D'Andrea AD, Zon LI: Erythropoietin receptor. Subunit structure and activation. J Clin Invest 1990;86:681-687.

-25 Chong ZZ, Kang JQ, Maiese K: Angiogenesis and plasticity: Role of erythropoietin in vascular systems. J Hematother Stem Cell Res 2002; 11:863-871.

-26 Hassan K, Gross B, Simri W, Rubinchik I, Cohen H, Jacobi J, Shasha SM, Kristal B: The presence of erythropoietin receptors in the human peripheral nervous system. Clin Nephrol 2004;61:127-129.

$\checkmark 27$ Chong ZZ, Kang JQ, Maiese K: Apaf-1, Bcl-xL, cytochrome $\mathrm{c}$, and caspase-9 form the critical elements for cerebral vascular protection by erythropoietin. J Cereb Blood Flow Metab 2003;23:320-330.

-28 Yamaji R, Okada T, Moriya M, Naito M, Tsuruo T, Miyatake K, Nakano Y: Brain capillary endothelial cells express two forms of erythropoietin receptor mRNA. Eur J Biochem 1996; 239:494-500.

29 Liu ZY, Chin K, Noguchi CT: Tissue specific expression of human erythropoietin receptor in transgenic mice. Dev Biol 1994;166:159-169.

-30 Liu C, Shen K, Liu Z, Noguchi CT: Regulated human erythropoietin receptor expression in mouse brain. J Biol Chem 1997;272:3239532400 .
31 Baciu I, Oprisiu C, Derevenco P, Vasile V, Muresan A, Hriscu M, Chis I: The brain and other sites of erythropoietin production. Rom $\mathrm{J}$ Physiol 2000;37:3-14.

32 Chikuma M, Masuda S, Kobayashi T, Nagao M, Sasaki R: Tissue-specific regulation of erythropoietin production in the murine kidney, brain, and uterus. Am J Physiol Endocrinol Metab 2000;279:E1242-E1248.

33 Marti HH, Wenger RH, Rivas LA, Straumann U, Digicaylioglu M, Henn V, Yonekawa Y, Bauer C, Gassmann M: Erythropoietin gene expression in human, monkey and murine brain. Eur J Neurosci 1996;8:666-676.

$\checkmark 34$ Stolze I, Berchner-Pfannschmidt U, Freitag P, Wotzlaw C, Rossler J, Frede S, Acker H, Fandrey J: Hypoxia-inducible erythropoietin gene expression in human neuroblastoma cells. Blood 2002;100:2623-2628.

-35 Bernaudin M, Marti HH, Roussel S, Divoux D, Nouvelot A, MacKenzie ET, Petit E: A potential role for erythropoietin in focal permanent cerebral ischemia in mice. $\mathrm{J}$ Cereb Blood Flow Metab 1999;19:643-651.

-36 Broudy VC, Lin N, Brice M, Nakamoto B, Papayannopoulou T: Erythropoietin receptor characteristics on primary human erythroid cells. Blood 1991;77:2583-2590.

>37 Bauer C: The oxygen sensor that controls EPO production: Facts and fancies. J Perinat Med 1995;23:7-12.

38 Hewitson KS, McNeill LA, Schofield CJ: Modulating the hypoxia-inducible factor signaling pathway: Applications from cardiovascular disease to cancer. Curr Pharm Des 2004;10: 821-833.

39 Wang GL, Semenza GL: Purification and characterization of hypoxia-inducible factor 1 . J Biol Chem 1995;270:1230-1237.

40 Hoffman M: A new role for gases: Neurotransmission. Science 1991;252:1788.

41 Huang LE, Gu J, Schau M, Bunn HF: Regulation of hypoxia-inducible factor 1alpha is mediated by an $\mathrm{O}_{2}$-dependent degradation domain via the ubiquitin-proteasome pathway. Proc Natl Acad Sci USA 1998;95:7987-7992.

42 Maxwell PH, Wiesener MS, Chang GW, Clifford SC, Vaux EC, Cockman ME, Wykoff CC, Pugh CW, Maher ER, Ratcliffe PJ: The tumour suppressor protein VHL targets hypoxia-inducible factors for oxygen-dependent proteolysis. Nature 1999;399:271-275.

43 Bunn HF, Gu J, Huang LE, Park JW, Zhu H: Erythropoietin: A model system for studying oxygen-dependent gene regulation. J Exp Biol 1998;201:1197-1201.

44 Zaman K, Ryu H, Hall D, O’Donovan K, Lin KI, Miller MP, Marquis JC, Baraban JM, Semenza GL, Ratan RR: Protection from oxidative stress-induced apoptosis in cortical neuronal cultures by iron chelators is associated with enhanced DNA binding of hypoxia-inducible factor-1 and ATF-1/CREB and increased expression of glycolytic enzymes, p21(waf1/ cip1), and erythropoietin. J Neurosci 1999;19: 9821-9830.
5 Ruscher K, Isaev N, Trendelenburg G, Weih M, Iurato L, Meisel A, Dirnagl U: Induction of hypoxia inducible factor 1 by oxygen glucose deprivation is attenuated by hypoxic preconditioning in rat cultured neurons. Neurosci Lett 1998;254:117-120.

46 Heidbreder M, Frohlich F, Johren O, Dendorfer A, Qadri F, Dominiak P: Hypoxia rapidly activates HIF-3alpha mRNA expression. FASEB J 2003; 17:1541-1543.

47 Yasuda Y, Masuda S, Chikuma M, Inoue K, Nagao M, Sasaki R: Estrogen-dependent production of erythropoietin in uterus and its implication in uterine angiogenesis. J Biol Chem 1998;273:25381-25387.

48 Masuda S, Kobayashi T, Chikuma M, Nagao M, Sasaki R: The oviduct produces erythropoietin in an estrogen- and oxygen-dependent manner. Am J Physiol Endocrinol Metab 2000; 278:E1038-E1044.

49 Obara N, Imagawa S, Nakano Y, Suzuki N, Yamamoto M, Nagasawa T: Suppression of erythropoietin gene expression by cadmium depends on inhibition of HIF-1, not stimulation of GATA-2. Arch Toxicol 2003;77:267273.

50 Nagai A, Nakagawa E, Choi HB, Hatori K, Kobayashi S, Kim SU: Erythropoietin and erythropoietin receptors in human CNS neurons, astrocytes, microglia, and oligodendrocytes grown in culture. J Neuropathol Exp Neurol 2001;60:386-392.

51 Studer L, Csete M, Lee SH, Kabbani N, Walikonis J, Wold B, McKay R: Enhanced proliferation, survival, and dopaminergic differentiation of CNS precursors in lowered oxygen. $\mathbf{J}$ Neurosci 2000;20:7377-7383.

52 Shingo T, Sorokan ST, Shimazaki T, Weiss S: Erythropoietin regulates the in vitro and in vivo production of neuronal progenitors by mammalian forebrain neural stem cells. J Neurosci 2001;21:9733-9743.

53 Lee JY, Koh HC, Chang MY, Park CH, Lee YS, Lee SH: Erythropoietin and bone morphogenetic protein 7 mediate ascorbate-induced dopaminergic differentiation from embryonic mesencephalic precursors. Neuroreport 2003; 14:1401-1404.

54 Tabira T, Konishi Y, Gallyas F Jr: Neurotrophic effect of hematopoietic cytokines on cholinergic and other neurons in vitro. Int $\mathbf{J}$ Dev Neurosci 1995;13:241-252.

55 Sakanaka M, Wen TC, Matsuda S, Masuda S, Morishita E, Nagao M, Sasaki R: In vivo evidence that erythropoietin protects neurons from ischemic damage. Proc Natl Acad Sci USA 1998;95:4635-4640.

56 Kumral A, Uysal N, Tugyan K, Sonmez A, Yilmaz O, Gokmen N, Kiray M, Genc S, Duman N, Koroglu TF, Ozkan H, Genc K: Erythropoietin improves long-term spatial memory deficits and brain injury following neonatal hypoxia-ischemia in rats. Behav Brain Res 2004;153: 77-86. 
-57 Sadamoto Y, Igase K, Sakanaka M, Sato K, Otsuka H, Sakaki S, Masuda S, Sasaki R: Erythropoietin prevents place navigation disability and cortical infarction in rats with permanent occlusion of the middle cerebral artery. Biochem Biophys Res Commun 1998;253:2632.

58 Calapai G, Marciano MC, Corica F, Allegra A, Parisi A, Frisina N, Caputi AP, Buemi M Erythropoietin protects against brain ischemic injury by inhibition of nitric oxide formation. Eur J Pharmacol 2000;401:349-356.

>59 Wang CH, Liang CL, Huang LT, Liu JK, Hung $\mathrm{PH}$, Sun A, Hung KS: Single intravenous injection of naked plasmid DNA encoding erythropoietin provides neuroprotection in hypoxiaischemia rats. Biochem Biophys Res Commun 2004;314:1064-1071.

-60 Grasso G, Buemi M, Alafaci C, Sfacteria A Passalacqua M, Sturiale A, Calapai G, De Vico G, Piedimonte G, Salpietro FM, Tomasello F: Beneficial effects of systemic administration of recombinant human erythropoietin in rabbits subjected to subarachnoid hemorrhage. Proc Natl Acad Sci USA 2002;99:5627-5631.

-61 Kaptanoglu E, Solaroglu I, Okutan O, Surucu HS, Akbiyik F, Beskonakli E: Erythropoietin exerts neuroprotection after acute spinal cord injury in rats: Effect on lipid peroxidation and early ultrastructural findings. Neurosurg Rev 2004;27:113-120.

-62 Chong ZZ, Kang JQ, Maiese K: Hematopoietic factor erythropoietin fosters neuroprotection through novel signal transduction cascades. J Cereb Blood Flow Metab 2002;22:503-514.

-63 Bocker-Meffert S, Rosenstiel P, Rohl C, Warneke N, Held-Feindt J, Sievers J, Lucius R: Erythropoietin and VEGF promote neural outgrowth from retinal explants in postnatal rats. Invest Ophthalmol Vis Sci 2002;43:20212026.

-64 Grimm C, Wenzel A, Groszer M, Mayser H, Seeliger M, Samardzija M, Bauer C, Gassmann M, Reme CE: HIF-1-induced erythropoietin in the hypoxic retina protects against light-induced retinal degeneration. Nat Med 2002;8: 718-724.

65 Campana WM, Myers RR: Exogenous erythropoietin protects against dorsal root ganglion apoptosis and pain following peripheral nerve injury. Eur J Neurosci 2003; 18:1497-1506.

-66 Sugawa M, Sakurai Y, Ishikawa-Ieda Y, Suzuki $\mathrm{H}$, Asou H: Effects of erythropoietin on glial cell development; oligodendrocyte maturation and astrocyte proliferation. Neurosci Res 2002 ; 44:391-403.

-67 Martinez-Estrada OM, Rodriguez-Millan E, Gonzalez-De Vicente E, Reina M, Vilaro S, Fabre M: Erythropoietin protects the in vitro blood-brain barrier against VEGF-induced permeability. Eur J Neurosci 2003;18:25382544 .
68 Buemi M, Allegra A, Corica F, Floccari F, D'Avella D, Aloisi C, Calapai G, Iacopino G, Frisina N: Intravenous recombinant erythropoietin does not lead to an increase in cerebrospinal fluid erythropoietin concentration. Nephrol Dial Transplant 2000; 15:422-423.

69 Chong ZZ, Kang JQ, Maiese K: Erythropoietin is a novel vascular protectant through activation of Akt1 and mitochondrial modulation of cysteine proteases. Circulation 2002;106: 2973-2979.

70 Risau W: Mechanisms of angiogenesis. Nature 1997;386:671-674.

71 Burri PH, Djonov V: Intussusceptive angiogenesis - The alternative to capillary sprouting. Mol Aspects Med 2002;23:S1-27.

72 Hanahan D, Folkman J: Patterns and emerging mechanisms of the angiogenic switch during tumorigenesis. Cell 1996;86:353-364.

73 Folkman J, Klagsbrun M: Angiogenic factors. Science 1987;235:442-447.

74 Anagnostou A, Lee ES, Kessimian N, Levinson R, Steiner M: Erythropoietin has a mitogenic and positive chemotactic effect on endothelial cells. Proc Natl Acad Sci USA 1990;87:59785982.

75 Ashley RA, Dubuque SH, Dvorak B, Woodward SS, Williams SK, Kling PJ: Erythropoietin stimulates vasculogenesis in neonatal rat mesenteric microvascular endothelial cells. Pediatr Res 2002;51:472-478.

76 Heeschen C, Aicher A, Lehmann R, Fichtlscherer S, Vasa M, Urbich C, Mildner-Rihm C, Martin H, Zeiher AM, Dimmeler S: Erythropoietin is a potent physiologic stimulus for endothelial progenitor cell mobilization. Blood 2003;102:1340-1346.

77 Carlini RG, Reyes AA, Rothstein M: Recombinant human erythropoietin stimulates angiogenesis in vitro. Kidney Int 1995;47:740-745.

78 Jaquet K, Krause K, Tawakol-Khodai M, Geidel S, Kuck KH: Erythropoietin and VEGF exhibit equal angiogenic potential. Microvasc Res 2002;64:326-333.

79 Crivellato E, Nico B, Vacca A, Djonov V, Presta M, Ribatti D: Recombinant human erythropoietin induces intussusceptive microvascular growth in vivo. Leukemia 2004; 18:331-336.

80 Krupinski J, Kaluza J, Kumar P, Kumar S, Wang JM: Role of angiogenesis in patients with cerebral ischemic stroke. Stroke 1994;25: 1794-1798.

81 Wei L, Erinjeri JP, Rovainen CM, Woolsey TA: Collateral growth and angiogenesis around cortical stroke. Stroke 2001;32:2179-2184.

82 Yalcin S, Muftuoglu S, Cetin E, Sarer B, Yildirim BA, Zeybek D, Orhan B: Protection against cisplatin-induced nephrotoxicity by recombinant human erythropoietin. Med Oncol 2003; 20:169-174.

83 Cai Z, Manalo DJ, Wei G, Rodriguez ER, FoxTalbot K, Lu H, Zweier JL, Semenza GL: Hearts from rodents exposed to intermittent hypoxia or erythropoietin are protected against ischemia-reperfusion injury. Circulation 2003; 108:79-85.
84 Semenza GL: $\mathrm{O}_{2}$-regulated gene expression: Transcriptional control of cardiorespiratory physiology by HIF-1. J Appl Physiol 2004;96: 1170-1177.

85 Parsa CJ, Kim J, Riel RU, Pascal LS, Thompson RB, Petrofski JA, Matsumoto A, Stamler JS, Koch WJ: Cardioprotective effects of erythropoietin in the reperfused ischemic heart: A potential role for cardiac fibroblasts. J Biol Chem 2004;279:20655-20662.

86 Wright GL, Hanlon P, Amin K, Steenbergen C, Murphy E, Arcasoy MO: Erythropoietin receptor expression in adult rat cardiomyocytes is associated with an acute cardioprotective effect for recombinant erythropoietin during ischemia-reperfusion injury. FASEB J 2004;18: 1031-1033.

87 van der Meer P, Voors AA, Lipsic E, van Gilst WH, van Veldhuisen DJ: Erythropoietin in cardiovascular diseases. Eur Heart J 2004;25: 285-291.

88 Tramontano AF, Muniyappa R, Black AD, Blendea MC, Cohen I, Deng L, Sowers JR, Cutaia MV, El-Sherif N: Erythropoietin protects cardiac myocytes from hypoxia-induced apoptosis through an Akt-dependent pathway. Biochem Biophys Res Commun 2003;308: 990-994.

89 Parsa CJ, Matsumoto A, Kim J, Riel RU, Pascal LS, Walton GB, Thompson RB, Petrofski JA, Annex BH, Stamler JS, Koch WJ: A novel protective effect of erythropoietin in the infarcted heart. J Clin Invest 2003;112:9991007.

90 Moon C, Krawczyk M, Ahn D, Ahmet I, Paik D, Lakatta EG, Talan MI: Erythropoietin reduces myocardial infarction and left ventricular functional decline after coronary artery ligation in rats. Proc Natl Acad Sci USA 2003;100: 11612-11617.

91 Goldberg N, Lundin AP, Delano B, Friedman EA, Stein RA: Changes in left ventricular size, wall thickness, and function in anemic patients treated with recombinant human erythropoietin. Am Heart J 1992;124:424-427.

92 Low-Friedrich I, Grutzmacher P, Marz W, Bergmann M, Schoeppe W: Therapy with recombinant human erythropoietin reduces cardiac size and improves heart function in chronic hemodialysis patients. Am J Nephrol 1991;11:54-60.

93 Calvillo L, Latini R, Kajstura J, Leri A, Anversa P, Ghezzi P, Salio M, Cerami A, Brines M: Recombinant human erythropoietin protects the myocardium from ischemia-reperfusion injury and promotes beneficial remodeling. Proc Natl Acad Sci USA 2003;100:4802-4806.

94 Silverberg DS, Wexler D, Sheps D, Blum M, Keren G, Baruch R, Schwartz D, Yachnin T, Steinbruch S, Shapira I, Laniado S, Iaina A: The effect of correction of mild anemia in severe, resistant congestive heart failure using subcutaneous erythropoietin and intravenous iron: A randomized controlled study. J Am Coll Cardiol 2001;37:1775-1780. 
-95 Silverberg DS, Wexler D, Blum M, Tchebiner JZ, Sheps D, Keren G, Schwartz D, Baruch R, Yachnin T, Shaked M, Schwartz I, Steinbruch S, Iaina A: The effect of correction of anaemia in diabetics and non-diabetics with severe resistant congestive heart failure and chronic renal failure by subcutaneous erythropoietin and intravenous iron. Nephrol Dial Transplant 2003;18:141-146.

-96 Arur S, Uche UE, Rezaul K, Fong M, Scranton V, Cowan AE, Mohler W, Han DK: Annexin $\mathrm{I}$ is an endogenous ligand that mediates apoptotic cell engulfment. Dev Cell 2003;4: 587-598.

-97 Hanayama R, Tanaka M, Miyasaka K, Aozasa K, Koike M, Uchiyama Y, Nagata S Autoimmune disease and impaired uptake of apoptotic cells in MFG-E8-deficient mice. Science 2004;304:1147-1150.

$>98$ Hatori K, Nagai A, Heisel R, Ryu JK, Kim SU: Fractalkine and fractalkine receptors in human neurons and glial cells. J Neurosci Res 2002;69:418-426.

>99 Lauber K, Bohn E, Krober SM, Xiao YJ, Blumenthal SG, Lindemann RK, Marini P, Wiedig C, Zobywalski A, Baksh S, Xu Y, Autenrieth IB, Schulze-Osthoff K, Belka C, Stuhler $\mathrm{G}$, Wesselborg S: Apoptotic cells induce migration of phagocytes via caspase-3-mediated release of a lipid attraction signal. Cell 2003; 113:717-730.

$\checkmark 100$ Fadok VA, de Cathelineau A, Daleke DL, Henson PM, Bratton DL: Loss of phospholipid asymmetry and surface exposure of phosphatidylserine is required for phagocytosis of apoptotic cells by macrophages and fibroblasts. J Biol Chem 2001;276:1071-1077.

101 Maiese K, Vincent AM: Membrane asymmetry and DNA degradation: Functionally distinct determinants of neuronal programmed cell death. J Neurosci Res 2000;59:568-580.

-102 Kang JQ, Chong ZZ, Maiese K: Critical role for Akt 1 in the modulation of apoptotic phosphatidylserine exposure and microglial activation. Mol Pharmacol 2003;64:557-569.

-103 Hoffmann PR, deCathelineau AM, Ogden CA, Leverrier Y, Bratton DL, Daleke DL, Ridley AJ, Fadok VA, Henson PM: Phosphatidylserine (PS) induces PS receptor-mediated macropinocytosis and promotes clearance of apoptotic cells. J Cell Biol 2001;155: 649-659.

104 Chong ZZ, Kang JQ, Maiese K: Metabotropic glutamate receptors promote neuronal and vascular plasticity through novel intracellular pathways. Histol Histopathol 2003;18:173189.

-105 Maiese K, Chong ZZ: Nicotinamide: Necessary nutrient emerges as a novel cytoprotectant for the brain. Trends Pharmacol Sci 2003;24:228-232.

106 Chong ZZ, Kang JQ, Maiese K: Erythropoietin fosters both intrinsic and extrinsic neuronal protection through modulation of microglia, Akt 1, Bad, and caspase-mediated pathways. Br J Pharmacol 2003;138:1107-1118.
107 Kang JQ, Chong ZZ, Maiese K: Akt1 protects against inflammatory microglial activation through maintenance of membrane asymmetry and modulation of cysteine protease activity. J Neurosci Res 2003;74:37-51.

108 Nakano T, Ishimoto Y, Kishino J, Umeda M, Inoue $\mathrm{K}$, Nagata $\mathrm{K}$, Ohashi K, Mizuno K, Arita $\mathrm{H}$ : Cell adhesion to phosphatidylserine mediated by a product of growth arrest-specific gene 6. J Biol Chem 1997;272:2941129414.

109 Witting A, Muller P, Herrmann A, Kettenmann H, Nolte C: Phagocytic clearance of apoptotic neurons by microglia/brain macrophages in vitro: Involvement of lectin-, integrin-, and phosphatidylserine-mediated recognition. J Neurochem 2000;75:1060-1070.

110 Tanaka M, Sotomatsu A, Yoshida T, Hirai S, Nishida A: Detection of superoxide production by activated microglia using a sensitive and specific chemiluminescence assay and microglia-mediated $\mathrm{PC} 12 \mathrm{~h}$ cell death. J Neurochem 1994;63:266-270.

111 Sankarapandi S, Zweier JL, Mukherjee G, Quinn MT, Huso DL: Measurement and characterization of superoxide generation in microglial cells: Evidence for an NADPH oxidase-dependent pathway. Arch Biochem Biophys 1998;353:312-321.

112 Liu B, Hong JS: Role of microglia in inflammation-mediated neurodegenerative diseases: Mechanisms and strategies for therapeutic intervention. J Pharmacol Exp Ther 2003;304:1-7.

113 Combs CK, Karlo JC, Kao SC, Landreth GE: Beta-amyloid stimulation of microglia and monocytes results in TNFalpha-dependent expression of inducible nitric oxide synthase and neuronal apoptosis. J Neurosci 2001;21: 1179-1188.

114 Singhrao SK, Neal JW, Morgan BP, Gasque $\mathrm{P}$ : Increased complement biosynthesis by microglia and complement activation on neurons in Huntington's disease. Exp Neurol 1999;159:362-376.

115 Obal I, Jakab JS, Siklos L, Engelhardt JI: Recruitment of activated microglia cells in the spinal cord of mice by ALS IgG. Neuroreport 2001;12:2449-2452.

116 Rupalla K, Allegrini PR, Sauer D, Wiessner $\mathrm{C}$ : Time course of microglia activation and apoptosis in various brain regions after permanent focal cerebral ischemia in mice. Acta Neuropathol (Berl) 1998;96:172-178.

117 Sheng JG, Mrak RE, Griffin WS: Neuritic plaque evolution in Alzheimer's disease is accompanied by transition of activated microglia from primed to enlarged to phagocytic forms. Acta Neuropathol (Berl) 1997;94:1-5.

118 Chong ZZ, Lin SH, Kang JQ, Maiese K: Erythropoietin prevents early and late neuronal demise through modulation of Akt 1 and induction of caspase 1,3 , and 8. J Neurosci Res 2003;71:659-669.
119 Villa P, Bigini P, Mennini T, Agnello D, Laragione T, Cagnotto A, Viviani B, Marinovich M, Cerami A, Coleman TR, Brines M, Ghezzi P: Erythropoietin selectively attenuates cytokine production and inflammation in cerebral ischemia by targeting neuronal apoptosis. J Exp Med 2003;198:971-975.

120 Lemmon MA, Ferguson KM, Abrams CS: Pleckstrin homology domains and the cytoskeleton. FEBS Lett 2002;513:71-76.

121 Chong ZZ, Kang JQ, Maiese K: Akt1 drives endothelial cell membrane asymmetry and microglial activation through $\mathrm{Bcl}-\mathrm{x}(\mathrm{L})$ and caspase 1, 3, and 9. Exp Cell Res 2004;296: 196-207.

122 Simak J, Holada K, Vostal JG: Release of annexin V-binding membrane microparticles from cultured human umbilical vein endothelial cells after treatment with camptothecin. BMC Cell Biol 2002;3:11.

123 Morishita E, Masuda S, Nagao M, Yasuda Y, Sasaki R: Erythropoietin receptor is expressed in rat hippocampal and cerebral cortical neurons, and erythropoietin prevents in vitro glutamate-induced neuronal death. Neuroscience 1997;76:105-116.

124 Wang XQ, Vaziri ND: Erythropoietin depresses nitric oxide synthase expression by human endothelial cells. Hypertension 1999; 33:894-899.

125 Zhang J, Tan Z, Tran ND: Chemical hypoxiaischemia induces apoptosis in cerebromicrovascular endothelial cells. Brain Res 2000; 877:134-140.

126 Shimohama S: Apoptosis in Alzheimer's disease - An update. Apoptosis 2000;5:9-16.

127 Eckert A, Keil U, Marques CA, Bonert A, Frey C, Schussel K, Muller WE: Mitochondrial dysfunction, apoptotic cell death, and Alzheimer's disease. Biochem Pharmacol 2003;66:1627-1634.

128 El-Khodor BF, Oo TF, Kholodilov N, Burke RE: Ectopic expression of cell cycle markers in models of induced programmed cell death in dopamine neurons of the rat substantia nigra pars compacta. Exp Neurol 2003;179: 17-27.

129 Ferraro G, Alabed Y, Fournier A: Molecular targets to promote central nervous system regeneration. Curr Neurovasc Res 2004;1: 61-75.

130 Ekshyyan O, Aw TY: Apoptosis in acute and chronic neurological disorders. Front Biosci 2004;9:1567-1576.

131 Chong ZZ, Maiese K: Targeting WNT, protein kinase $\mathrm{B}$, and mitochondrial membrane integrity to foster cellular survival in the nervous system. Histol Histopathol 2004;19: 495-504.

132 Chong ZZ, Kang JQ, Maiese K: Essential cellular regulatory elements of oxidative stress in early and late phases of apoptosis in the central nervous system. Antioxid Redox Signal 2004;6:277-287. 
133 Dombroski D, Balasubramanian K, Schroit AJ: Phosphatidylserine expression on cell surfaces promotes antibody-dependent aggregation and thrombosis in beta2-glycoprotein Iimmune mice. J Autoimmun 2000;14:221229.

134 Jessel R, Haertel S, Socaciu C, Tykhonova S, Diehl HA: Kinetics of apoptotic markers in exogeneously induced apoptosis of EL4 cells. J Cell Mol Med 2002;6:82-92.

135 Maiese K, Chong ZZ: Insights into oxidative stress and potential novel therapeutic targets for Alzheimer disease. Restor Neurol Neurosci 2004;22:87-104.

$\checkmark 136$ Kiprianova I, Freiman TM, Desiderato S, Schwab S, Galmbacher R, Gillardon F, Spranger M: Brain-derived neurotrophic factor prevents neuronal death and glial activation after global ischemia in the rat. J Neurosci Res 1999;56:21-27.

137 Culmsee C, Junker V, Wolz P, Semkova I, Krieglstein J: Lubeluzole protects hippocampal neurons from excitotoxicity in vitro and reduces brain damage caused by ischemia. Eur J Pharmacol 1998;342:193-201.

138 Maiese K, Vincent AM: Critical temporal modulation of neuronal programmed cell injury. Cell Mol Neurobiol 2000;20:383-400.

139 Maiese K, TenBroeke M, Kue I: Neuroprotection of lubeluzole is mediated through the signal transduction pathways of nitric oxide. $\mathbf{J}$ Neurochem 1997;68:710-714.

140 Rong R, Ahn JY, Huang H, Nagata E, Kalman D, Kapp JA, Tu J, Worley PF, Snyder $\mathrm{SH}$, Ye K: PI3 kinase enhancer-Homer complex couples mGluRI to PI3 kinase, preventing neuronal apoptosis. Nat Neurosci 2003;6: 1153-1161.

141 Fabisiak JP, Kagan VE, Ritov VB, Johnson DE, Lazo JS: Bcl-2 inhibits selective oxidation and externalization of phosphatidylserine during paraquat-induced apoptosis. Am J Physiol 1997;272:C675-C684.

142 Casadevall N, Nataf J, Viron B, Kolta A, Kiladjian J-J, Martin-Dupont P, Michaud P, Papo T, Ugo V, Teyssandier I, Varet B, Mayeux P: Pure red-cell aplasia and antierythropoietin antibodies in patients treated with recombinant erythropoietin. $\mathrm{N}$ Engl $\mathrm{J}$ Med 2002;346:469-475.

143 Verdier F, Walrafen P, Hubert N, Chretien S Gisselbrecht S, Lacombe C, Mayeux P: Proteasomes regulate the duration of erythropoietin receptor activation by controlling downregulation of cell surface receptors. J Biol Chem 2000;275:18375-18381.

144 Watowich SS, Hilton DJ, Lodish HF: Activation and inhibition of erythropoietin receptor function: Role of receptor dimerization. Mol Cell Biol 1994;14:3535-3549.

145 Bazan JF: Structural design and molecular evolution of a cytokine receptor superfamily. Proc Natl Acad Sci USA 1990;87:69346938.

146 Mulcahy L: The erythropoietin receptor. Semin Oncol 2001;28:19-23.
147 Witthuhn BA, Quelle FW, Silvennoinen O, Yi T, Tang B, Miura O, Ihle JN: JAK2 associates with the erythropoietin receptor and is tyrosine phosphorylated and activated following stimulation with erythropoietin. Cell 1993;74:227-236.

148 Wilks AF, Harpur AG, Kurban RR, Ralph SJ, Zurcher G, Ziemiecki A: Two novel protein-tyrosine kinases, each with a second phosphotransferase-related catalytic domain, define a new class of protein kinase. Mol Cell Biol 1991;11:2057-2065.

149 Zhao Y, Wagner F, Frank SJ, Kraft AS: The amino-terminal portion of the JAK2 protein kinase is necessary for binding and phosphorylation of the granulocyte-macrophage colony-stimulating factor receptor beta $\mathrm{c}$ chain. $\mathrm{J}$ Biol Chem 1995;270:13814-13818.

150 Kawakami M, Sekiguchi M, Sato K, Kozaki S, Takahashi M: Erythropoietin receptor-mediated inhibition of exocytotic glutamate release confers neuroprotection during chemical ischemia. J Biol Chem 2001;276:3946939475.

151 Digicaylioglu M, Lipton SA: Erythropoietinmediated neuroprotection involves cross-talk between Jak2 and NF-kappaB signalling cascades. Nature 2001;412:641-647.

152 Damen JE, Wakao H, Miyajima A, Krosl J, Humphries RK, Cutler RL, Krystal G: Tyrosine 343 in the erythropoietin receptor positively regulates erythropoietin-induced cell proliferation and Stat5 activation. EMBO J 1995; 14:5557-5568.

153 Bittorf T, Sasse T, Wright M, Jaster R, Otte L, Schneider-Mergener J, Brock J: cDNA cloning and functional analysis of a truncated STAT5a protein from autonomously growing FDCP-1 cells. Cell Signal 2000;12:721-730.

154 Socolovsky M, Nam H, Fleming MD, Haase $\mathrm{VH}$, Brugnara $\mathrm{C}$, Lodish HF: Ineffective erythropoiesis in Stat5a(-/-)5b(-/-) mice due to decreased survival of early erythroblasts. Blood 2001;98:3261-3273.

155 Socolovsky M, Fallon AE, Wang S, Brugnara C, Lodish HF: Fetal anemia and apoptosis of red cell progenitors in Stat5a-/-5b-/- mice: A direct role for Stat5 in $\mathrm{Bcl}-\mathrm{X}(\mathrm{L})$ induction. Cell 1999;98:181-191.

156 Bao H, Jacobs-Helber SM, Lawson AE, Penta K, Wickrema A, Sawyer ST: Protein kinase B (c-Akt), phosphatidylinositol 3-kinase, and STAT5 are activated by erythropoietin (EPO) in HCD57 erythroid cells but are constitutively active in an EPO-independent, apoptosis-resistant subclone (HCD57-SREI cells). Blood 1999;93:3757-3773.

157 Bellacosa A, Testa JR, Staal SP, Tsichlis PN: A retroviral oncogene, akt, encoding a serinethreonine kinase containing an SH2-like region. Science 1991;254:274-277.

158 Franke TF, Tartof KD, Tsichlis PN: The SH2-like Akt homology (AH) domain of c-akt is present in multiple copies in the genome of vertebrate and invertebrate eucaryotes. Cloning and characterization of the Drosophila melanogaster c-akt homolog Dakt1. Oncogene 1994;9:141-148.
159 Owada Y, Utsunomiya A, Yoshimoto T, Kondo $\mathrm{H}$ : Expression of mRNA for Akt, serine-threonine protein kinase, in the brain during development and its transient enhancement following axotomy of hypoglossal nerve. J Mol Neurosci 1997;9:27-33.

160 Wick MJ, Dong LQ, Riojas RA, Ramos FJ, Liu F: Mechanism of phosphorylation of protein kinase B/Akt by a constitutively active 3phosphoinositide-dependent protein kinase1. J Biol Chem 2000;275:40400-40406.

161 Wick A, Wick W, Waltenberger J, Weller M, Dichgans J, Schulz JB: Neuroprotection by hypoxic preconditioning requires sequential activation of vascular endothelial growth factor receptor and Akt. J Neurosci 2002;22: 6401-6407.

162 Yamaguchi A, Tamatani M, Matsuzaki H, Namikawa K, Kiyama H, Vitek MP, Mitsuda $\mathrm{N}$, Tohyama M: Akt activation protects hippocampal neurons from apoptosis by inhibiting transcriptional activity of p53. J Biol Chem 2001;276:5256-5264.

163 Kim AH, Yano H, Cho H, Meyer D, Monks B, Margolis B, Birnbaum MJ, Chao MV: Akt 1 regulates a JNK scaffold during excitotoxic apoptosis. Neuron 2002;35:697-709.

164 Matsuzaki H, Tamatani M, Mitsuda N, Namikawa K, Kiyama H, Miyake S, Tohyama M: Activation of Akt kinase inhibits apoptosis and changes in Bcl-2 and Bax expression induced by nitric oxide in primary hippocampal neurons. J Neurochem 1999;73:20372046.

165 Weishaupt JH, Rohde G, Polking E, Siren AL, Ehrenreich H, Bahr M: Effect of erythropoietin axotomy-induced apoptosis in rat retinal ganglion cells. Invest Ophthalmol Vis Sci 2004;45:1514-1522.

166 Murashov AK, Ul Haq I, Hill C, Park E, Smith M, Wang X, Goldberg DJ, Wolgemuth DJ: Crosstalk between p38, Hsp25 and Akt in spinal motor neurons after sciatic nerve injury. Brain Res Mol Brain Res 2001;93:199208.

167 Chong ZZ, Li F, Maiese K: Activating Akt and the brain's resources to drive cellular survival and prevent inflammatory injury. Histol Histopathol, in press.

168 Miura O, Nakamura N, Ihle JN, Aoki N: Erythropoietin-dependent association of phosphatidylinositol 3-kinase with tyrosinephosphorylated erythropoietin receptor. J Biol Chem 1994;269:614-620.

169 Uddin S, Kottegoda S, Stigger D, Platanias LC, Wickrema A: Activation of the Akt/ FKHRL1 pathway mediates the antiapoptotic effects of erythropoietin in primary human erythroid progenitors. Biochem Biophys Res Commun 2000;275:16-19.

170 Dzietko M, Felderhoff-Mueser U, Sifringer M, Krutz B, Bittigau P, Thor F, Heumann R, Buhrer C, Ikonomidou C, Hansen HH: Erythropoietin protects the developing brain against $\mathrm{N}$-methyl- $D$-aspartate receptor antagonist neurotoxicity. Neurobiol Dis 2004;15: 177-187. 
171 Gilley J, Coffer PJ, Ham J: FOXO transcription factors directly activate bim gene expression and promote apoptosis in sympathetic neurons. J Cell Biol 2003; 162:613-622.

172 Dijkers PF, Birkenkamp KU, Lam EW, Thomas NS, Lammers JW, Koenderman L, Coffer PJ: FKHR-L1 can act as a critical effector of cell death induced by cytokine withdrawal: Protein kinase B-enhanced cell survival through maintenance of mitochondrial integrity. J Cell Biol 2002;156:531-542.

173 Brunet A, Bonni A, Zigmond MJ, Lin MZ, Juo P, Hu LS, Anderson MJ, Arden KC, Blenis J, Greenberg ME: Akt promotes cell survival by phosphorylating and inhibiting a Forkhead transcription factor. Cell 1999;96: 857-868.

174 Yu C, Rahmani M, Dai Y, Conrad D, Krystal G, Dent P, Grant S: The lethal effects of pharmacological cyclin-dependent kinase inhibitors in human leukemia cells proceed through a phosphatidylinositol 3-kinase/Akt-dependent process. Cancer Res 2003;63:18221833.

175 Rena G, Guo S, Cichy SC, Unterman TG, Cohen P: Phosphorylation of the transcription factor forkhead family member FKHR by protein kinase B. J Biol Chem 1999;274: 17179-17183.

176 Chong ZZ, Lin S-H, Maiese K: The NAD+ precursor nicotinamide governs neuronal survival during oxidative stress through protein kinase B coupled to FOXO3a and mitochondrial membrane potential. J Cereb Blood Flow Metab 2004;24:728-743.

- 177 Mahmud DL, M GA, Deb DK, Platanias LC, Uddin S, Wickrema A: Phosphorylation of forkhead transcription factors by erythropoietin and stem cell factor prevents acetylation and their interaction with coactivator p300 in erythroid progenitor cells. Oncogene 2002;21: 1556-1562.

$\checkmark 178$ Bhat RV, Shanley J, Correll MP, Fieles WE Keith RA, Scott CW, Lee CM: Regulation and localization of tyrosine 216 phosphorylation of glycogen synthase kinase-3beta in cellular and animal models of neuronal degeneration. Proc Natl Acad Sci USA 2000;97: 11074-11079.

179 Alvarez G, Munoz-Montano JR, Satrustegui J, Avila J, Bogonez E, Diaz-Nido J: Lithium protects cultured neurons against beta-amyloid-induced neurodegeneration. FEBS Lett 1999;453:260-264.

180 Loberg RD, Vesely E, Brosius FC 3rd: Enhanced glycogen synthase kinase-3beta activity mediates hypoxia-induced apoptosis of vascular smooth muscle cells and is prevented by glucose transport and metabolism. J Biol Chem 2002;277:41667-41673.

181 Yin H, Chao L, Chao J: Adrenomedullin protects against myocardial apoptosis after ischemia/reperfusion through activation of AktGSK signaling. Hypertension 2004;43:109_ 116.
182 Pei JJ, Braak E, Braak H, Grundke-Iqbal I, Iqbal K, Winblad B, Cowburn RF: Distribution of active glycogen synthase kinase 3 beta (GSK-3beta) in brains staged for Alzheimer disease neurofibrillary changes. J Neuropathol Exp Neurol 1999;58:1010-1019.

183 Aplin AE, Jacobsen JS, Anderton BH, Gallo JM: Effect of increased glycogen synthase kinase- 3 activity upon the maturation of the amyloid precursor protein in transfected cells. Neuroreport 1997;8:639-643.

184 Citron M, Vigo-Pelfrey C, Teplow DB, Miller C, Schenk D, Johnston J, Winblad B, Venizelos N, Lannfelt L, Selkoe DJ: Excessive production of amyloid beta-protein by peripheral cells of symptomatic and presymptomatic patients carrying the Swedish familial Alzheimer disease mutation. Proc Natl Acad Sci USA 1994;91:11993-11997.

185 Somervaille TC, Linch DC, Khwaja A: Growth factor withdrawal from primary human erythroid progenitors induces apoptosis through a pathway involving glycogen synthase kinase-3 and Bax. Blood 2001;98:13741381.

186 Datta SR, Dudek H, Tao X, Masters S, Fu H, Gotoh Y, Greenberg ME: Akt phosphorylation of BAD couples survival signals to the cell-intrinsic death machinery. Cell 1997;91: 231-241.

187 Dramsi S, Scheid MP, Maiti A, Hojabrpour P, Chen X, Schubert K, Goodlett DR, Aebersold R, Duronio V: Identification of a novel phosphorylation site, Ser-170, as a regulator of bad pro-apoptotic activity. J Biol Chem 2002;277:6399-6405.

188 Putcha GV, Deshmukh M, Johnson EM Jr: BAX translocation is a critical event in neuronal apoptosis: Regulation by neuroprotectants, BCL-2, and caspases. J Neurosci 1999; 19:7476-7485.

189 Gregoli PA, Bondurant MC: The roles of Bcl$\mathrm{X}(\mathrm{L})$ and apopain in the control of erythropoiesis by erythropoietin. Blood 1997;90: 630-640

190 Silva M, Grillot D, Benito A, Richard C, Nunez G, Fernandez-Luna JL: Erythropoietin can promote erythroid progenitor survival by repressing apoptosis through Bcl-XL and Bcl-2. Blood 1996;88:1576-1582.

191 Vairano M, Dello Russo C, Pozzoli G, Battaglia A, Scambia G, Tringali G, Aloe-Spiriti MA, Preziosi P, Navarra P: Erythropoietin exerts anti-apoptotic effects on rat microglial cells in vitro. Eur J Neurosci 2002;16:684692.

192 Kalwy SA, Akbar MT, Coffin RS, de Belleroche J, Latchman DS: Heat shock protein 27 delivered via a herpes simplex virus vector can protect neurons of the hippocampus against kainic-acid-induced cell loss. Brain Res Mol Brain Res 2003;111:91-103.

193 Latchman D: Protective effect of heat shock proteins in the nervous system. Curr Neurovasc Res 2004;1:21-27.
194 Beere HM, Wolf BB, Cain K, Mosser DD, Mahboubi A, Kuwana T, Tailor P, Morimoto RI, Cohen GM, Green DR: Heat-shock protein 70 inhibits apoptosis by preventing recruitment of procaspase- 9 to the Apaf- 1 apoptosome. Nat Cell Biol 2000;2:469-475.

195 Reed JC: Apoptosis-regulating proteins as targets for drug discovery. Trends Mol Med 2001;7:314-319.

196 Wang CY, Mayo MW, Korneluk RG, Goeddel DV, Baldwin AS Jr: NF-kappaB antiapoptosis: Induction of TRAF1 and TRAF2 and c-IAP1 and c-IAP2 to suppress caspase- 8 activation. Science 1998;281:1680-1683.

197 Tang G, Minemoto Y, Dibling B, Purcell NH, Li Z, Karin M, Lin A: Inhibition of JNK activation through NF-kappaB target genes. Nature 2001;414:313-317.

198 Zhan Q, Antinore MJ, Wang XW, Carrier F, Smith ML, Harris CC, Fornace AJ Jr: Association with $\mathrm{Cdc} 2$ and inhibition of $\mathrm{Cdc} 2 /$ Cyclin B1 kinase activity by the p53-regulated protein Gadd45. Oncogene 1999;18: 2892-2900.

199 De Smaele E, Zazzeroni F, Papa S, Nguyen DU, Jin R, Jones J, Cong R, Franzoso G: Induction of gadd45beta by NF-kappaB downregulates pro-apoptotic JNK signalling. Nature 2001;414:308-313.

200 Chen JW, Lin J, Madamanchi N, Trier TT, Campbell G: Apoptosis occurs in a new model of thermal brain injury. J Biomed Sci 2000; 7:459-465.

201 Figueroa YG, Chan AK, Ibrahim R, Tang Y, Burow ME, Alam J, Scandurro AB, Beckman BS: NF-kappaB plays a key role in hypoxiainducible factor-1-regulated erythropoietin gene expression. Exp Hematol 2002;30: 1419-1427.

202 Matsushita H, Johnston MV, Lange MS, Wilson MA: Protective effect of erythropoietin in neonatal hypoxic ischemia in mice. Neuroreport 2003; 14:1757-1761.

203 Bal-Price A, Brown GC: Nitric-oxide-induced necrosis and apoptosis in PC12 cells mediated by mitochondria. J Neurochem 2000; 75:1455-1464.

204 Lin SH, Vincent A, Shaw T, Maynard KI, Maiese K: Prevention of nitric oxide-induced neuronal injury through the modulation of independent pathways of programmed cell death. J Cereb Blood Flow Metab 2000;20: 1380-1391.

205 Zhou H, Li XM, Meinkoth J, Pittman RN: Akt regulates cell survival and apoptosis at a postmitochondrial level. J Cell Biol 2000;151: 483-494.

206 Bachelder RE, Wendt MA, Fujita N, Tsuruo T, Mercurio AM: The cleavage of Akt/protein kinase B by death receptor signaling is an important event in detachment-induced apoptosis. J Biol Chem 2001;276:3470234707.

207 Earnshaw WC, Martins LM, Kaufmann SH: Mammalian caspases: Structure, activation, substrates, and functions during apoptosis. Annu Rev Biochem 1999;68:383-424. 
208 Shi Y: Caspase activation: Revisiting the induced proximity model. Cell 2004;117:855858 .

209 Hofmann K, Bucher P, Tschopp J: The CARD domain: A new apoptotic signalling motif. Trends Biochem Sci 1997;22:155156.

210 Ashkenazi A, Dixit VM: Death receptors: Signaling and modulation. Science 1998;281: 1305-1308.

-211 Varfolomeev EE, Schuchmann M, Luria V, Chiannilkulchai N, Beckmann JS, Mett IL, Rebrikov D, Brodianski VM, Kemper OC, Kollet O, Lapidot T, Soffer D, Sobe T, Avraham KB, Goncharov T, Holtmann H, Lonai P, Wallach D: Targeted disruption of the mouse Caspase 8 gene ablates cell death induction by the TNF receptors, Fas/Apo1, and DR 3 and is lethal prenatally. Immunity 1998 ; 9:267-276.

-212 Juo P, Kuo CJ, Yuan J, Blenis J: Essential requirement for caspase-8/FLICE in the initiation of the Fas-induced apoptotic cascade. Curr Biol 1998;8:1001-1008.

-213 Li H, Zhu H, Xu CJ, Yuan J: Cleavage of BID by caspase 8 mediates the mitochondrial damage in the Fas pathway of apoptosis. Cell 1998;94:491-501.

$\checkmark 214$ Yin XM, Luo Y, Cao G, Bai L, Pei W, Kuharsky DK, Chen J: Bid-mediated mitochondrial pathway is critical to ischemic neuronal apoptosis and focal cerebral ischemia. $\mathrm{J}$ Biol Chem 2002;277:42074-42081.

-215 Liu X, Kim CN, Yang J, Jemmerson R, Wang $\mathrm{X}$ : Induction of apoptotic program in cell-free extracts: Requirement for dATP and cytochrome c. Cell 1996;86:147-157.

-216 Cosulich SC, Worrall V, Hedge PJ, Green S, Clarke PR: Regulation of apoptosis by $\mathrm{BH} 3$ domains in a cell-free system. Curr Biol 1997; 7:913-920.

-217 Hu Y, Benedict MA, Ding L, Nunez G: Role of cytochrome $\mathrm{c}$ and dATP/ATP hydrolysis in Apaf-1-mediated caspase-9 activation and apoptosis. EMBO J 1999; 18:3586-3595.

-218 Li P, Nijhawan D, Budihardjo I, Srinivasula SM, Ahmad M, Alnemri ES, Wang X: Cytochrome $\mathrm{c}$ and dATP-dependent formation of Apaf-1/caspase-9 complex initiates an apoptotic protease cascade. Cell 1997;91:479489.

-219 Takahashi H, Nakamura S, Asano K, Kinouchi $\mathrm{M}$, Ishida-Yamamoto A, Iizuka $\mathrm{H}$ : Fas antigen modulates ultraviolet B-induced apoptosis of SVHK cells: Sequential activation of caspases 8, 3, and 1 in the apoptotic process. Exp Cell Res 1999;249:291-298.

-220 Vanags DM, Porn-Ares MI, Coppola S, Burgess $\mathrm{DH}$, Orrenius $\mathrm{S}$ : Protease involvement in fodrin cleavage and phosphatidylserine exposure in apoptosis. J Biol Chem 1996;271: 31075-31085.

-221 Charvet C, Alberti I, Luciano F, Jacquel A, Bernard A, Auberger P, Deckert M: Proteolytic regulation of Forkhead transcription factor FOXO3a by caspase-3-like proteases. Oncogene 2003;22:4557-4568.
222 Engels IH, Stepczynska A, Stroh C, Lauber K, Berg C, Schwenzer R, Wajant H, Janicke RU, Porter AG, Belka C, Gregor M, SchulzeOsthoff K, Wesselborg S: Caspase-8/FLICE functions as an executioner caspase in anticancer drug-induced apoptosis. Oncogene 2000; 19:4563-4573.

223 Stegh AH, Barnhart BC, Volkland J, Algeciras-Schimnich A, Ke N, Reed JC, Peter ME: Inactivation of caspase- 8 on mitochondria of Bcl-xL-expressing MCF7-Fas cells: Role for the bifunctional apoptosis regulator protein. $\mathrm{J}$ Biol Chem 2002;277:4351-4360.

224 Rossler OG, Giehl KM, Thiel G: Neuroprotection of immortalized hippocampal neurones by brain-derived neurotrophic factor and Raf-1 protein kinase: Role of extracellular signal-regulated protein kinase and phosphatidylinositol 3-kinase. J Neurochem 2004; 88:1240-1252.

225 Nagata Y, Todokoro K: Requirement of activation of JNK and p38 for environmental stress-induced erythroid differentiation and apoptosis and of inhibition of ERK for apoptosis. Blood 1999;94:853-863.

226 Le-Niculescu H, Bonfoco E, Kasuya Y, Claret FX, Green DR, Karin M: Withdrawal of survival factors results in activation of the JNK pathway in neuronal cells leading to Fas ligand induction and cell death. Mol Cell Biol 1999; 19:751-763.

-227 Suzuki M, Tetsuka T, Yoshida S, Watanabe N, Kobayashi M, Matsui N, Okamoto T: The role of p38 mitogen-activated protein kinase in IL-6 and IL-8 production from the TNFalpha- or IL-1beta-stimulated rheumatoid synovial fibroblasts. FEBS Lett 2000;465:2327.

228 Cao J, Semenova MM, Solovyan VT, Han J, Coffey ET, Courtney MJ: Distinct requirements for $\mathrm{p} 38$-alpha and JNK stress-activated protein kinases in different forms of apoptotic neuronal death. J Biol Chem 2004;279: 35903-35913.

229 Bagnard D, Sainturet N, Meyronet D, Perraut M, Miehe M, Roussel G, Aunis D, Belin MF, Thomasset N: Differential MAP kinases activation during semaphorin3A-induced repulsion or apoptosis of neural progenitor cells. Mol Cell Neurosci 2004;25:722-731.

230 Campana WM, Misasi R, O'Brien JS: Identification of a neurotrophic sequence in erythropoietin. Int J Mol Med 1998;1:235-241.

231 Jacobs-Helber SM, Ryan JJ, Sawyer ST: JNK and p38 are activated by erythropoietin (EPO) but are not induced in apoptosis following EPO withdrawal in EPO-dependent HCD 57 cells. Blood 2000;96:933-940.

232 Nagata Y, Takahashi N, Davis RJ, Todokoro $\mathrm{K}$ : Activation of p38 MAP kinase and JNK but not ERK is required for erythropoietininduced erythroid differentiation. Blood 1998;92:1859-1869.

233 Chong ZZ, Lin SH, Maiese K: Nicotinamide modulates mitochondrial membrane potential and cysteine protease activity during cerebral vascular endothelial cell injury. J Vasc Res 2002;39:131-147.
234 Cross TG, Scheel-Toellner D, Henriquez NV, Deacon E, Salmon M, Lord JM: Serine/ threonine protein kinases and apoptosis. Exp Cell Res 2000;256:34-41.

235 Deacon EM, Pongracz J, Griffiths G, Lord JM: Isoenzymes of protein kinase C: Differential involvement in apoptosis and pathogenesis. Mol Pathol 1997;50:124-131.

236 Ruvolo PP, Deng X, Carr BK, May WS: A functional role for mitochondrial protein kinase Calpha in $\mathrm{Bcl} 2$ phosphorylation and suppression of apoptosis. J Biol Chem 1998;273: 25436-25442.

237 Myklebust JH, Smeland EB, Josefsen D, Sioud M: Protein kinase C-alpha isoform is involved in erythropoietin-induced erythroid differentiation of $\mathrm{CD} 34(+)$ progenitor cells from human bone marrow. Blood 2000;95: 510-518.

238 von Lindern M, Parren-van Amelsvoort M, van Dijk T, Deiner E, van den Akker E, van Emst-de Vries S, Willems P, Beug H, Lowenberg B: Protein kinase $\mathrm{C}$ alpha controls erythropoietin receptor signaling. $\mathrm{J}$ Biol Chem 2000;275:34719-34727.

239 Shi Y, Rafiee P, Su J, Pritchard KA Jr, Tweddell JS, Baker JE: Acute cardioprotective effects of erythropoietin in infant rabbits are mediated by activation of protein kinases and potassium channels. Basic Res Cardiol 2004; 99:173-182.

240 Mladenovic J, Kay NE: Erythropoietin induces rapid increases in intracellular free calcium in human bone marrow cells. J Lab Clin Med 1988;112:23-27.

241 Assandri R, Egger M, Gassmann M, Niggli E, Bauer C, Forster I, Gorlach A: Erythropoietin modulates intracellular calcium in a human neuroblastoma cell line. J Physiol 1999;516: 343-352.

242 Masuda S, Nagao M, Takahata K, Konishi Y, Gallyas F Jr, Tabira T, Sasaki R: Functional erythropoietin receptor of the cells with neural characteristics. Comparison with receptor properties of erythroid cells. J Biol Chem 1993;268:11208-11216.

243 Miller BA, Barber DL, Bell LL, Beattie BK, Zhang MY, Neel BG, Yoakim M, Rothblum LI, Cheung JY: Identification of the erythropoietin receptor domain required for calcium channel activation. J Biol Chem 1999;274: 20465-20472.

244 Koshimura K, Murakami Y, Sohmiya M, Tanaka J, Kato Y: Effects of erythropoietin on neuronal activity. J Neurochem 1999;72: 2565-2572.

245 Maiese K, Ahmad I, TenBroeke M, Gallant J: Metabotropic glutamate receptor subtypes independently modulate neuronal intracellular calcium. J Neurosci Res 1999;55:472-485.

246 Henry DH, Bowers P, Romano MT, Provenzano R: Epoetin alfa. Clinical evolution of a pleiotropic cytokine. Arch Intern Med 2004; 164:262-276. 
247 Miyashita K, Tojo A, Kimura K, Goto A, Omata M, Nishiyama K, Fujita T: Blood pressure response to erythropoietin injection in hemodialysis and predialysis patients. $\mathrm{Hy}-$ pertens Res 2004;27:79-84.

-248 Schaefer RM, Leschke M, Strauer BE, Heidland $\mathrm{A}$ : Blood rheology and hypertension in hemodialysis patients treated with erythropoietin. Am J Nephrol 1988;8:449-453.

249 Steffen HM, Brunner R, Muller R, Degenhardt S, Pollok M, Lang R, Baldamus CA: Peripheral hemodynamics, blood viscosity, and the renin-angiotensin system in hemodialysis patients under therapy with recombinant human erythropoietin. Contrib Nephrol 1989;76:292-298.

250 Roger SD, Grasty MS, Baker LR, Raine AE: Effects of oxygen breathing and erythropoietin on hypoxic vasodilation in uremic anemia. Kidney Int 1992;42:975-980.

251 Kaupke CJ, Kim S, Vaziri ND: Effect of erythrocyte mass on arterial blood pressure in dialysis patients receiving maintenance erythropoietin therapy. J Am Soc Nephrol 1994;4: 1874-1878.
252 Hand MF, Haynes WG, Johnstone HA, Anderton JL, Webb DJ: Erythropoietin enhances vascular responsiveness to norepinephrine in renal failure. Kidney Int 1995;48: 806-813.

253 Lebel M, Kingma I, Grose JH, Langlois S: Hemodynamic and hormonal changes during erythropoietin therapy in hemodialysis patients. J Am Soc Nephrol 1998;9:97-104.

254 Akimoto $\mathrm{T}$, Kusano E, Inaba T, Iimura O, Takahashi H, Ikeda H, Ito C, Ando Y, Ozawa K, Asano Y: Erythropoietin regulates vascular smooth muscle cell apoptosis by a phosphatidylinositol 3 kinase-dependent pathway. Kidney Int 2000;58:269-282.

-255 Bode-Boger SM, Boger RH, Kuhn M, Radermacher J, Frolich JC: Recombinant human erythropoietin enhances vasoconstrictor tone via endothelin-1 and constrictor prostanoids. Kidney Int 1996;50:1255-1261.

256 del Castillo D, Raij L, Shultz PJ, Tolins JP: The pressor effect of recombinant human erythropoietin is not due to decreased activity of the endogenous nitric oxide system. Nephrol Dial Transplant 1995;10:505-508.

257 Wilcox CS, Deng X, Doll AH, Snellen H, Welch WJ: Nitric oxide mediates renal vasodilation during erythropoietin-induced polycythemia. Kidney Int 1993;44:430-435.
258 Vaziri ND, Zhou XJ, Naqvi F, Smith J, Oveisi F, Wang ZQ, Purdy RE: Role of nitric oxide resistance in erythropoietin-induced hypertension in rats with chronic renal failure. Am J Physiol 1996;271:E113-E122.

259 Ni Z, Wang XQ, Vaziri ND: Nitric oxide metabolism in erythropoietin-induced hypertension: Effect of calcium channel blockade. Hypertension 1998:32:724-729.

260 Wiessner C, Allegrini PR, Ekatodramis D, Jewell UR, Stallmach T, Gassmann M: Increased cerebral infarct volumes in polyglobulic mice overexpressing erythropoietin. J Cereb Blood Flow Metab 2001;21:857-864.

261 Gil JM, Leist M, Popovic N, Brundin P, Petersen A: Asialoerythropoetin is not effective in the R6/2 line of Huntington's disease mice. BMC Neurosci 2004;5:17.

262 Maiese K, Chong ZZ, Kang J: Transformation into treatment: Novel therapeutics that begin within the cell; in Maiese K (ed): Neuronal and Vascular Plasticity: Elucidating Basic Cellular Mechanisms for Future Therapeutic Discovery. Norwell, Kluwer Academic Publishers, 2003, pp 1-26. 